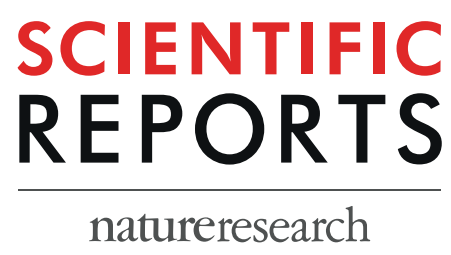

\title{
OPEN Improving the drug-likeness of inspiring natural products - evaluation of the antiparasitic activity against Trypanosoma cruzi through semi-synthetic and simplified analogues of licarin A
}

Thiago R. Morais ${ }^{1}$, Geanne A. Alves Conserva ${ }^{2}$, Marina T. Varela ${ }^{1}$, Thais A. Costa-Silva ${ }^{2}$, Fernanda Thevenard ${ }^{2}$, Vitor Ponci ${ }^{1}$, Ana Fortuna ${ }^{3,4}$, Amílcar C. Falcão $0^{3,4}$, Andre G. Tempone ${ }^{5}$, João Paulo S. Fernandes ${ }^{1 *} \&$ João Henrique G. Lago ${ }^{2 *}$

Neolignan licarin A (1) was isolated from leaves of Nectandra oppositifolia (Lauraceae) and displayed activity against trypomastigote forms of the etiologic agent of American trypanosomiasis, Trypanosoma cruzi. Aiming for the establishment of SAR, five different compounds $(1 \mathrm{a}-1 \mathrm{e})$ were prepared and tested against $T$. cruzi. The 2-allyl derivative of licarin A (1d) exhibited higher activity against trypomastigotes of $T$. cruzi $\left(\mathrm{IC}_{50}=5.0 \mu \mathrm{M}\right.$ and $\left.\mathrm{SI}=9.0\right)$, while its heterocyclic derivative le displayed $\mathrm{IC}_{50}$ of $10.5 \mu \mathrm{M}$ and reduced toxicity against NCTC cells $(\mathrm{SI}>19.0)$. However, these compounds presented limited oral bioavailability estimation $\left(<85 \%, \operatorname{Papp}<1.0 \times 10^{-6} \mathrm{~cm} / \mathrm{s}\right)$ in parallel artificial membrane permeability assays (PAMPA) due to excessive lipophilicity. Based on these results, different simplified structures of licarin A were designed: vanillin (2), vanillyl alcohol (3), isoeugenol (4), and eugenol (5), as well as its corresponding methyl (a), acetyl (b), O-allyl (c), and C-allyl (d) analogues. Vanillin (2) and its acetyl derivative (2b) displayed expressive activity against intracellular amastigotes of $T$. cruzi with $\mathrm{IC}_{50}$ values of 5.5 and $5.6 \mu \mathrm{M}$, respectively, and reduced toxicity against NCTC cells $\left(\mathrm{CC}_{50}>200 \mu \mathrm{M}\right)$. In addition, these simplified analogues showed a better permeability profile $\left(\right.$ Papp $\left.>1.0 \times 10^{-6} \mathrm{~cm} / \mathrm{s}\right)$ on PAMPA models, resulting in improved drug-likeness. Vanillyl alcohol acetyl derivative (3b) and isoeugenol methyl derivative (4a) displayed activity against the extracellular forms of $T$. cruzi (trypomastigotes) with $\mathrm{IC}_{50}$ values of 5.1 and $8.8 \mu \mathrm{M}$ respectively. Based on these results, compounds with higher selectivity index against extracellular forms of the parasite (1d, 1e, 3d, and 4a) were selected for a mechanism of action study. After a short incubation period (1 h) all compounds increased the reactive oxygen species (ROS) levels of trypomastigotes, suggesting cellular oxidative stress. The ATP levels were increased after two hours of incubation, possibly involving a high energy expenditure of the parasite to control the homeostasis. Except for compound 4a, all compounds induced hyperpolarization of mitochondrial membrane potential, demonstrating a mitochondrial imbalance. Considering the unique mitochondria apparatus of $T$. cruzi and the lethal alterations induced by structurally based on licarin A, these compounds are interesting hits for future drug discovery studies in Chagas disease.

${ }^{1}$ Institute of Environmental, Chemical and Pharmaceutical Sciences, Universidade Federal de São Paulo, São Paulo, 09972-270, Brazil. ' Center of Natural Sciences and Humanities, Universidade Federal do ABC, São Paulo, 09210-580, Brazil. ${ }^{3}$ Laboratory of Pharmacology, Faculty of Pharmacy of University of Coimbra, 3000-370, Coimbra, Portugal. ${ }^{4} \mathrm{CIBIT/ICNAS}$ - Coimbra Institute for Biomedical Imaging and Translational Research, University of Coimbra, 3000370, Coimbra, Portugal. ${ }^{5}$ Centre for Parasitology and Mycology, Instituto Adolfo Lutz, São Paulo, 01246-000, Brazil. *email: joao.fernandes@unifesp.br; joao.lago@ufabc.edu.br 


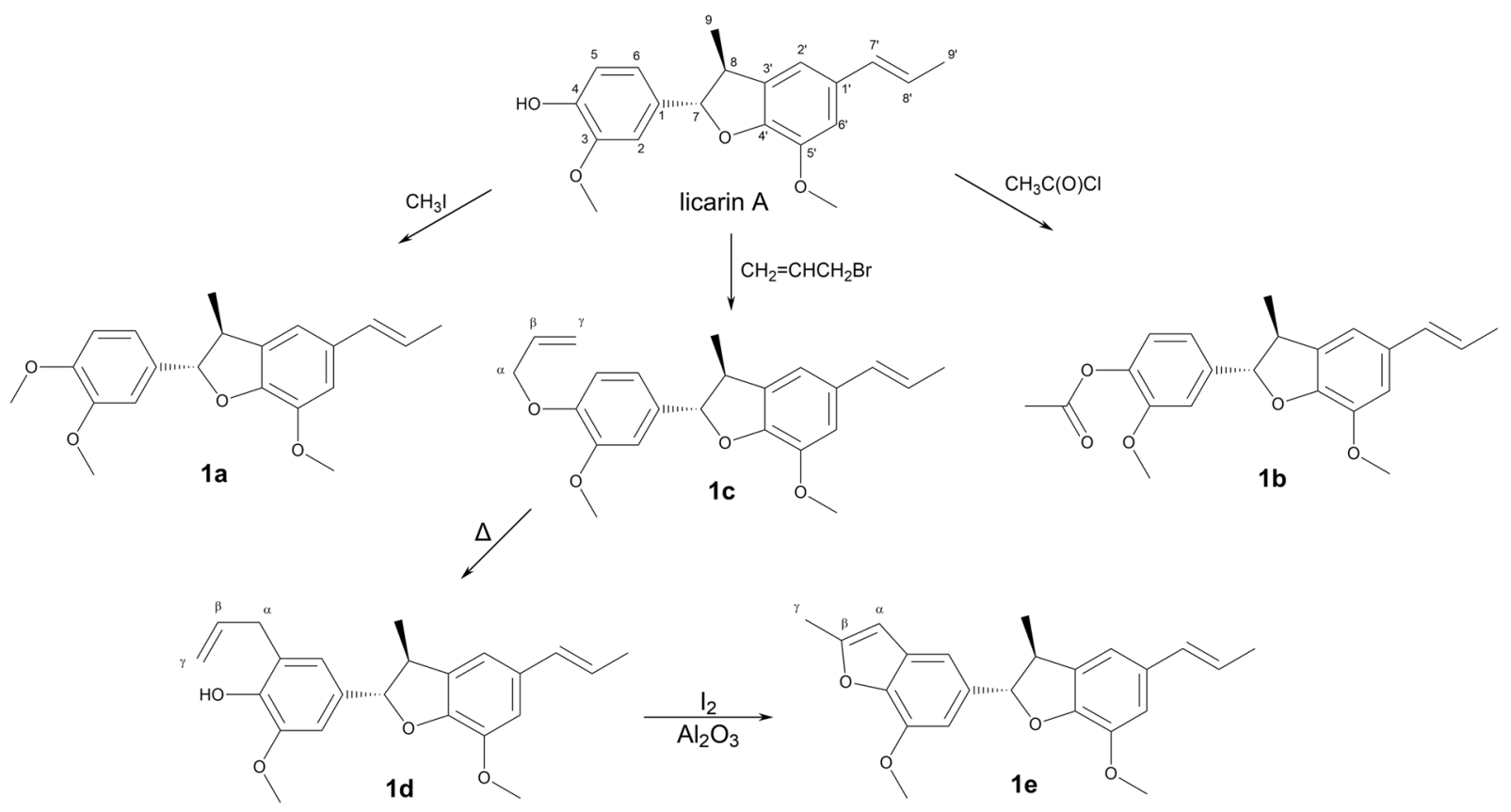

Figure 1. Licarin A (1) and semi-synthetic derivatives 1a - 1e.

Chagas disease (CD) is a parasitic infection caused by Trypanosoma cruzi, endemic in Latin America and recently found in non-endemic countries of North America, Europe and Asia. The main form of transmission depends on the presence of a vector, being Triatoma infestans the most common ${ }^{1}$. It is estimated that over eight million people are infected by the parasite and 70 million are at risk, living on endemic areas or in places where the control of other forms of transmission (oral, blood transfusion or organ transplant) is not rigid ${ }^{2}$. CD is a two-stage disease: the acute phase, characterized by the high parasitaemia, and invasion by trypomastigote forms of different organs and the chronic phase, which may be latent for decades before appearance of clinical signs and usually associated with the development of cardiomyopathy ${ }^{3,4}$. The available therapy for the treatment of CD is actually restricted to two approved drugs: benznidazole and nifurtimox, remains a controversial issue, with contradictory results in the chronic phase of the disease $e^{5-8}$. Furthermore, these nitrocompounds showed several side effects associated to prolonged treatment regimens.

Several clinical trials involving drug-repositioning (such as antifungal azoles) were carried out as well as studies involving new molecules, but none have reached the market yet ${ }^{4}$. Therefore, new effective drugs for the treatment of CD are still needed. The Drugs for Neglected Diseases initiative (DNDi) defines that a desirable hit compound should present considerable efficacy $\left(\mathrm{IC}_{50}<10 \mu \mathrm{M}\right)$, selectivity $(>10$-fold over mammalian cells) and adequate oral bioavailability ${ }^{9}$.

Natural products have always been a source of a great variety of bioactive molecules, mostly substances from the organism secondary metabolism. Many drugs available in the market are natural products as found in nature or compounds designed based on the structure and activity of these natural products (semi-synthetic or completely synthetic) ${ }^{10}$. The biodiversity of plants makes them a commonly explored source of novel bioactive compounds, providing molecules with distinct structures, complex or simple, with huge chemical variety ${ }^{11}$. Several research groups are focused on the isolation and identification of novel compounds with antimicrobial activity from plant extracts, aiming to use them as prototypes for drug discovery against Chagas disease ${ }^{12}$. In this context, licarin A is a neolignan isolated from different plant species with reported activity against Mycobacterium tuberculosis ${ }^{13,14}$, Schistosoma mansoni ${ }^{15}$, Trypanosoma cruzi $^{15-17}$, and Leishmania major ${ }^{18}$. Considering the promising activity against T. cruzi and the considerable amounts of licarin A isolated from the leaves of Nectandra oppositifolia (Lauraceae), this compound was selected for preparation of semi-synthetic analogues to further pharmacophore exploitation. Thereafter, licarin A was obtained in pure form and five semi-synthetic and twenty-one analogues were designed by the molecular simplification approach. The main objective was to assess a structure-activity relationship (SAR) for the antiparasitic activity of licarin A, determine the pharmacophore of these molecules, to predict their oral bioavailability through the in vitro parallel artificial membrane permeability assay (PAMPA), and also to study the mechanism of action of the compounds with higher selectivity.

\section{Results and Discussion}

Chemical characterization of licarin A (1). NMR $\left({ }^{1} \mathrm{H}\right.$ and $\left.{ }^{13} \mathrm{C}\right)$ and HRESIMS data of the isolated compound from $n$-hexane extract from leaves of N. oppositifolia were compared with those reported in the literature ${ }^{19}$, allowing the identification of licarin A in $99 \%$ of purity as indicated by HPLC.

Design and preparation of licarin A analogues. Five semi-synthetic analogues of licarin A (compounds 1a-1e, Fig. 1) were prepared through classical organic processes such as methylation, acetylation, allylation and Claisen rearrangement. Compound 1e was obtained through iodine-promoted cyclization of the corresponding 

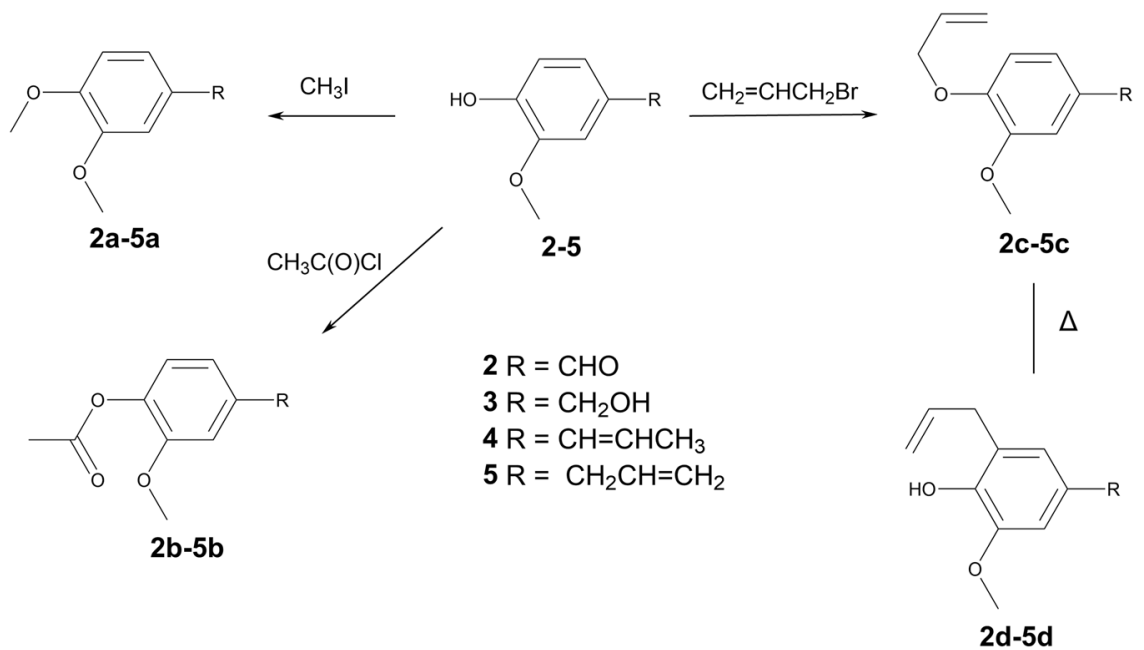

Figure 2. Simplified analogues (2a-d - 5a-d) of licarin A (1).

ortho-allylphenol followed by deiodination with basic alumina using a previously reported method ${ }^{20,21}$. Their structures were confirmed by analysis of $\operatorname{NMR}\left({ }^{1} \mathrm{H}\right.$ and $\left.{ }^{13} \mathrm{C}\right)$ and HRESIMS data. Considering that licarin A exhibited a considerable molecular complexity given by the asymmetry of the dihydrobenzofurane heterocycle, a molecular simplification approach was also applied in its structure (Fig. 2).

Licarin A and its semi-synthetic analogues were designed to check the role of the phenolic hydroxyl in the biological activity of the natural product. However, licarin A present reduced solubility, that would impair the pharmacokinetic properties of this molecule in vivo. Considering that the semi-synthetic analogues 1a-1e present modifications that lead to increased lipophilicity (as noted by the log P values - Table 1), it is expected that these compounds would present a solubility in water even worse than the natural prototype, and thus analogues with improved solubility profile should be considered. The simplification strategy has been widely used to make complex molecules with promising activity simpler, which allows keeping the pharmacophore unit in the analogue but with better drug-like properties (solubility and ADME profile), as well as providing compounds with simpler structure and cheaper obtaining process ${ }^{22,23}$. Moreover, these simplified analogues would keep or improve the antitrypanosomal activity of licarin A, but with better drug-likeness and water solubility. Accordingly, simplified analogues of vanillin (2), vanillyl alcohol (3), isoeugenol (4), and eugenol (5) were prepared by using the same modifications performed to licarin A, generating the corresponding analogues a - d (Fig. 3) which were chemically characterized by analysis of NMR $\left({ }^{1} \mathrm{H}\right.$ and $\left.{ }^{13} \mathrm{C}\right)$ and HRESIMS data.

Antitrypanosomal activity. The antitrypanosomal potentials of the semi-synthetic analogues 1a, 1b, 1d and 1e were superior to the natural licarin A (1), as showed in Table 1. However, these compounds showed appreciable activity only against the trypomastigote form and were not active against the intracellular amastigote. The DNDi states that a good antichagasic agent should present activity against both forms of the parasite ${ }^{5,9}$. Efficacy against trypomastigotes also contributes on the clinical outcome, since this avoids the increases in parasitaemia that can contribute to the spreading of the parasites into healthy cells ${ }^{9}$. On the other hand, several compounds showed no important mammalian cytotoxicity to the maximal tested concentration of $200 \mu \mathrm{M}$, and even though some analogues showed some toxicity to the cells, the selectivity index (SI) were $>19$ for the intracellular amastigotes stage of the parasite, making these compounds interesting hits for further studies.

The most active semi-synthetic compound in the series was 1d, which showed an $\mathrm{IC}_{50}$ of $5.0 \pm 0.8 \mu \mathrm{M}$ against the trypomastigotes, followed by compound $1 \mathbf{e}\left(\mathrm{IC}_{50}\right.$ of $\left.10.5 \pm 5.7 \mu \mathrm{M}\right)$. This suggests that the presence of an additional substitution in the aromatic ring of licarin A contributed to the antitrypanosomal activity. However, the presence of the phenolic hydroxyl led to increased cytotoxicity to mammalian cells, as can be observed in the results for compound $\mathbf{1 d}\left(\mathrm{CC}_{50}\right.$ of $\left.45.5 \pm 16.7 \mu \mathrm{M}\right)$. Conversely, moderate cytotoxicity was detected to acetyl derivative $\mathbf{1 b}\left(\mathrm{CC}_{50} 67.2 \pm 24.6 \mu \mathrm{M}\right)$. This can be attributed to the hydrolysis by cellular esterases, which can hydrolyse $\mathbf{1 b}$ to the phenol $\mathbf{1}$ after its penetration into the cells, thus exerting cytotoxic effect.

Compounds with more stable substituents in the hydroxyl group (such as $\mathbf{1 a}, \mathbf{1 c}$ and $\mathbf{1 d}$ ) showed no important cytotoxic effect against NCTC cells. This corroborates to our hypothesis on the toxicophoric role of the phenolic hydroxyl, and thus this functional group should be avoided to increase the selectivity of such compounds. However, some of the cytotoxicity can also be attributed to the excessive lipophilicity of such compounds. It is known that lipophilicity affects not only the water solubility of the drugs, but also the ADME properties and accordingly the toxicity ${ }^{24,25}$. Highly lipophilic compounds $(\log \mathrm{P}>5)$ tend to bind to hydrophobic sites in the cells, increasing the promiscuity and the cytotoxicity. Considering this aspect, analogues with reduced lipophilicity but maintaining the probable pharmacophore of licarin A were designed. Our pharmacophore hypothesis regards on the presence of the vanillin-like (Fig. 3, red) or the isoeugenol-like (Fig. 3, blue) motifs. Thus, simplified analogues from vanillin (2), vanillyl alcohol (3), isoeugenol (4), and eugenol (5) may present the pharmacophore motifs with less lipophilicity and improved water solubility indeed. The results presented in Table 1 show that analogues $\mathbf{2}, \mathbf{2 b}, \mathbf{3 b}, \mathbf{4}, \mathbf{4 a}, \mathbf{4 b}$ and $\mathbf{4 d}$ kept the pharmacophore to exert antiparasitic activity against 


\begin{tabular}{|l|l|l|l|l|l|l|l|l|}
\hline & \multicolumn{2}{l}{$\mathbf{I C}_{\mathbf{5 0}}(\boldsymbol{\mu M})$} & $\mathbf{C C}_{\mathbf{5 0}}(\boldsymbol{\mu M})$ & \multicolumn{2}{l}{ SI } & \multicolumn{2}{l}{ Clog } & \multicolumn{2}{l|}{ Papp $\left(\mathbf{1 0}^{-6}\right)$} \\
\cline { 2 - 6 } & trypo & Ama & NCTC & trypo & ama & $\mathbf{P}$ & GIT & BBB \\
\hline $\mathbf{1}$ & $54.3 \pm 8.9$ & $>100$ & $>200$ & $>3.7$ & - & 4.51 & 0.85 & 2.37 \\
\hline $\mathbf{1 a}$ & $28.0 \pm 10.2$ & $>100$ & $>200$ & $>7.1$ & - & 4.65 & 0.42 & 4.26 \\
\hline $\mathbf{1 b}$ & $17.9 \pm 2.9$ & $>100$ & $67.2 \pm 24.6$ & 3.7 & - & 4.42 & 1.02 & 0.34 \\
\hline $\mathbf{1 c}$ & $>100$ & $>100$ & $>200$ & - & - & 5.39 & 0.43 & 0.24 \\
\hline $\mathbf{1 d}$ & $5.0 \pm 0.8$ & $>100$ & $45.5 \pm 16.7$ & 9.0 & - & 5.61 & 0.38 & 0.28 \\
\hline $\mathbf{1 e}$ & $10.5 \pm 5.7$ & $>100$ & $>200$ & $>19.0$ & - & 5.17 & 0.55 & 0.23 \\
\hline $\mathbf{2}$ & $>100$ & $5.5 \pm 0.6$ & $>200$ & - & $>36.4$ & 1.22 & 1.41 & 6.15 \\
\hline $\mathbf{2 a}$ & $>100$ & $>100$ & $>200$ & - & - & 1.37 & 20.70 & 7.00 \\
\hline $\mathbf{2 b}$ & $>100$ & $5.6 \pm 0.3$ & $>200$ & - & $>35.6$ & 1.14 & 17.40 & 4.70 \\
\hline $\mathbf{2 c}$ & $>100$ & $>100$ & $>200$ & - & - & 2.10 & 1.60 & 5.35 \\
\hline $\mathbf{2 d}$ & $>100$ & $>100$ & $>200$ & - & - & 2.32 & 1.57 & 1.25 \\
\hline $\mathbf{3}$ & $>100$ & $>100$ & $>200$ & - & - & 0.74 & 0.18 & 0.64 \\
\hline $\mathbf{3 a}$ & $>100$ & $>100$ & $>200$ & - & - & 0.89 & 2.22 & 2.18 \\
\hline $\mathbf{3 b}$ & $5.1 \pm 0.7$ & $>100$ & $45.8 \pm 14.9$ & 9.0 & - & 0.66 & 5.07 & 3.67 \\
\hline $\mathbf{3 c}$ & $>100$ & $>100$ & $>200$ & - & - & 1.62 & 1.90 & 4.74 \\
\hline $\mathbf{3 d}$ & $>100$ & $>100$ & $>200$ & - & - & 1.84 & 3.47 & 3.47 \\
\hline $\mathbf{4}$ & $50.7 \pm 17.4$ & $>100$ & $>200$ & $>4.0$ & - & 2.64 & 6.17 & 1.60 \\
\hline $\mathbf{4 a}$ & $8.8 \pm 2.0$ & $>100$ & $>200$ & $>25.0$ & - & 2.78 & 15.90 & 1.29 \\
\hline $\mathbf{4 b}$ & $54.6 \pm 10.2$ & $>100$ & $>200$ & $>3.7$ & - & 2.55 & 15.00 & 1.32 \\
\hline $\mathbf{4 c}$ & $>100$ & $>100$ & $>200$ & - & - & 3.51 & 0.13 & 0.20 \\
\hline $\mathbf{4 d}$ & $21.2 \pm 3.7$ & $10.4 \pm 0.9$ & $>200$ & $>9.5$ & $>19.1$ & 3.73 & 1.20 & 0.74 \\
\hline $\mathbf{5}$ & $>100$ & $>100$ & $>200$ & - & - & 2.61 & 14.40 & 3.98 \\
\hline $\mathbf{5 a}$ & $>100$ & $>100$ & $>200$ & - & - & 2.76 & 2.35 & 1.56 \\
\hline $\mathbf{5 b}$ & $>100$ & $>100$ & $>200$ & - & - & 2.52 & 2.81 & 2.28 \\
\hline $\mathbf{5 c}$ & $>100$ & $>100$ & $>200$ & - & - & 3.49 & 1.21 & 0.32 \\
\hline $\mathbf{5 d}$ & $>100$ & $>100$ & $>200$ & - & - & 3.71 & 0.65 & 0.32 \\
\hline $\mathbf{B n z}$ & $5.5 \pm 0.9$ & $18.7 \pm 2.6$ & $>200$ & $>36.4$ & $>10.7$ & - & - & - \\
\hline & & & & & & & & \\
\hline
\end{tabular}

Table 1. Anti-T. cruzi activity, cytotoxicity in mammalian cells, selectivity index, $\log \mathrm{P}$ estimation, and apparent permeability for the licarin A, semisynthetic derivatives, simplified analogues, and positive control benznidazole $(\mathrm{Bnz})$.

the trypomastigote form, and some of them $(2,2 \mathbf{b}$ and $\mathbf{4 d})$ also presented activity against the amastigote form of the parasite. Moreover, almost all compounds showed no relevant toxicity for the mammalian cells (except for compound $\mathbf{3 b}$ ), reinforcing the hypothesis of the contribution of excessive lipophilicity on the cytotoxic effect.

Isoeugenol derivatives $(\mathbf{4 a - 4 d})$ showed the best activity profile against trypomastigote forms, with $\mathrm{IC}_{50}$ values ranging from $54.6 \pm 10.2$ to $8.8 \pm 2.0 \mu \mathrm{M}$ and thus yielding good selectivity towards the parasites. Among them, compound $4 \mathbf{d}$ can be highlighted, since it also presented activity against the amastigotes ( $\mathrm{IC}_{50}$ of $10.4 \pm 0.9 \mu \mathrm{M}$ ) and a high SI value (>9.5). This result suggests that a possible pharmacophore fragment on licarin A structure is the isoeugenol moiety, as showed in Fig. 4. Furthermore, this data is corroborated by the poor activity showed by the eugenol derivatives ${ }^{5}$, on which the isomerization of the unsaturation of the terminal carbon was detrimental to the activity and thus this double bond seems to be part of the pharmacophore. Additionally, the substitution of the hydroxyl on isoeugenol (4) by a methyl group (4a) and the ortho-substitution in the aromatic ring (4d) seems to increase the antiparasitic activity. As shown in Table 1, compound $\mathbf{4 c}$ was the unique isoeugenol derivative that did not display activity, suggesting that the presence of the allyloxy group is detrimental to the activity. The same is also observed for the compound 1c.

Vanillin (2) and its acetyl derivative $\mathbf{2 b}$ showed interesting activity against the amastigotes of T. cruzi. Despite the high activity presented by such compounds, this effect may be due the presence of the aldehyde, which is a reactive group and may exert antiparasitic effect through covalent interaction with parasitic proteins. Moreover, compound $\mathbf{2} \mathbf{b}$ reinforces the hypothesis of a hydrolysis-dependent effect in the intracellular environment, since compounds $\mathbf{2}$ and $\mathbf{2 b}$ showed the same activity. The explanation to the activity of such compounds only at amastigotes can be related to the higher activity of aldehyde reductases in the extracellular form of the parasite. Sanchez-Moreno and co-workers showed that epimastigotes (but not amastigotes) of T. cruzi, release ethanol to the environment ${ }^{26}$. Cazzulo et al. reported differences in the metabolism of the different forms of T. cruzi, suggesting that the extracellular forms present higher aldehyde reductase activity than the amastigotes ${ }^{27}$, showing that benzaldehydes are reduced faster than the benzyl alcohols are oxidized by the parasitic enzymes ${ }^{28}$. Considering that the corresponding alcohols were inactive in both forms of the parasite, the higher aldehyde reduction rate in the trypomastigotes may explain the reason for the activity of the aldehydes only against the amastigotes ${ }^{29}$.

Mechanism of action studies. Compounds $\mathbf{1 d}, \mathbf{1 e}, \mathbf{3} \mathbf{b}$, and $\mathbf{4 a}$ exhibited higher activity against T. cruzi trypomastigotes and were selected for studies of mechanism of action, to understand the possible alterations 


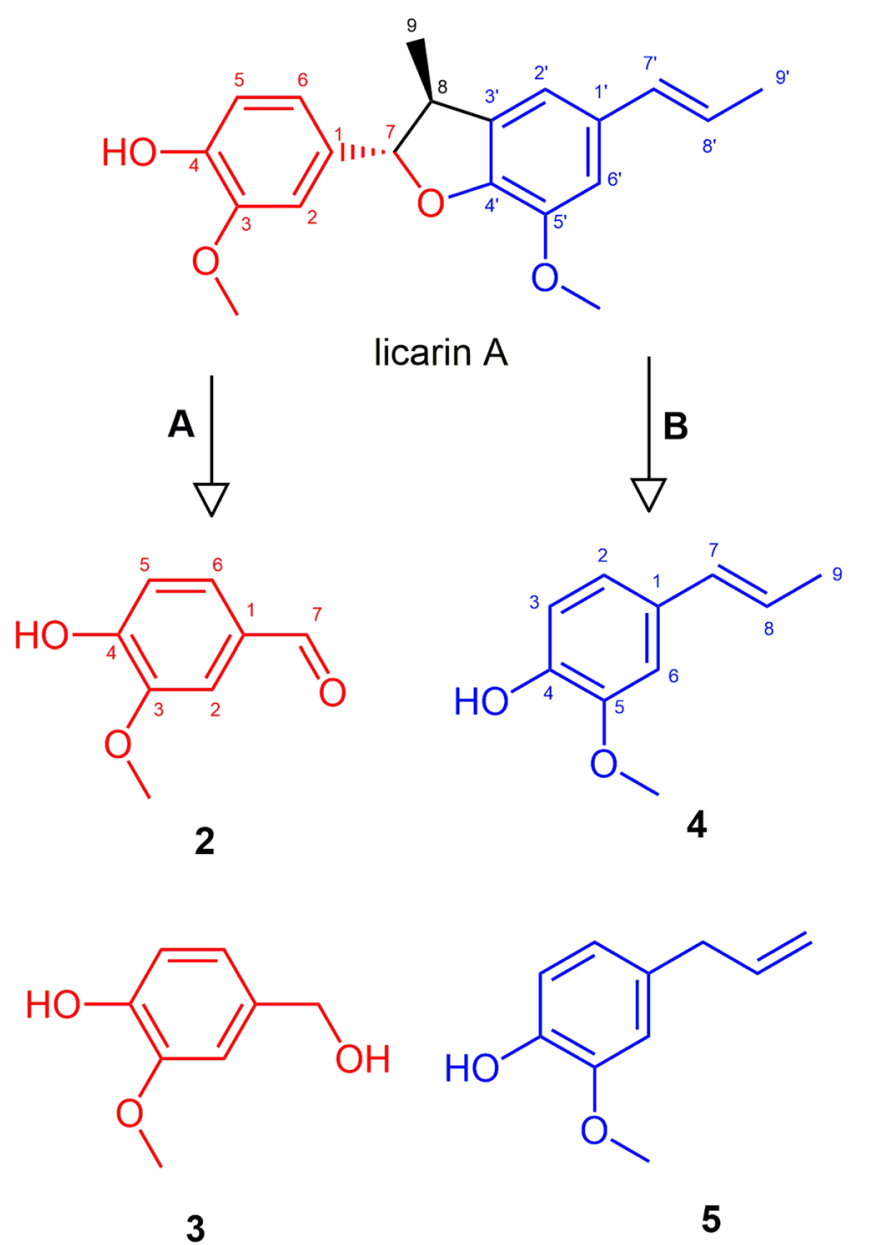

Figure 3. Molecular simplification approach to design the analogues 2-5 of licarin A (1). Note that licarin is comprised by a vanillin-like subunit (red - part A) and an isoeugenol-like subunit (blue - part B), which was explored in the search for the pharmacophore in licarin A.<smiles>C/C=C/c1cc(OC)c2c(c1)[C@H](C)[C@H](c1ccc(O)c(OC)c1)O2</smiles>

1<smiles>C/C=C/c1ccc(OC)c(OC)c1</smiles>

$4 a$<smiles>C=CCc1cc(/C=C/C)cc(OC(C)(Cl)Cl)c1O</smiles>

4d

Figure 4. Possible pharmacophore fragment on licarin A (1) structure (blue) suggested by the activity observed to isoeugenol derivatives $\mathbf{4 a}$ and $\mathbf{4 d}$, and the auxophore moieties (magenta).

caused by these compounds in the plasma membrane permeability and the mitochondria of T. cruzi trypomastigotes. The fluorescent probe Sytox Green enters damaged cells and binds to nucleic acid, increasing 500 -fold the fluorescence levels. Alterations in the plasma membrane can lead to a total parasite breakdown affecting morphology, fluidity, ion transport, and consequent cell death ${ }^{30}$. In our study, no changes in the fluorescence levels were observed for all the studied compounds, with exception of 1 e after $120 \mathrm{~min}$ of incubation (Fig. 5) when compared to untreated parasites. The production of reactive oxygen species (ROS) was determined with the cell permeant fluorescence probe $\mathrm{H}_{2}$ DCFDA. After $1 \mathrm{~h}$ of treatment with all studied compounds, it was possible to observe an increased ROS generation by the trypomastigotes, followed by a drop of the levels after $2 \mathrm{~h}$ (Fig. 6A,B), showing the cellular apparatus controlling the oxidative stress caused by these highly toxic radicals. The redox imbalance occurs when the endogenous antioxidants fail to remove the excessive ROS produced, which leads to oxidative stress ${ }^{31}$. The bioenergetic system of the parasite was highly compromised, as a result of the increased ATP production after $2 \mathrm{~h}$ of incubation with all compounds. This energy expenditure to control the homeostasis was clearly observed in the parasites incubated with all compounds, with exception of compound 1e, which 


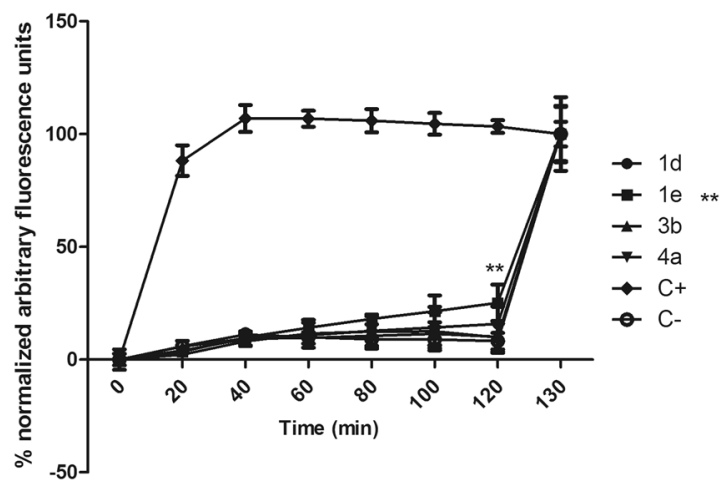

Figure 5. Plasma membrane permeability analysis on T. cruzi trypomastigotes with the probe Sytox Green treated with compounds $\mathbf{1 d}, \mathbf{1 e}, \mathbf{3 b}$ and $\mathbf{4 a}$ at the respective $\mathrm{IC}_{50}$ values. As positive $(\mathrm{C}+)$ and negative $(\mathrm{C}-)$ controls were used trypomastigotes treated with TX-100 at 0.5\% (maximum permeabilization) and untreated T. cruzi parasites (minimum permeabilization), respectively. One representative experiment of two assays is shown. $* * \mathrm{p}<0.005$.
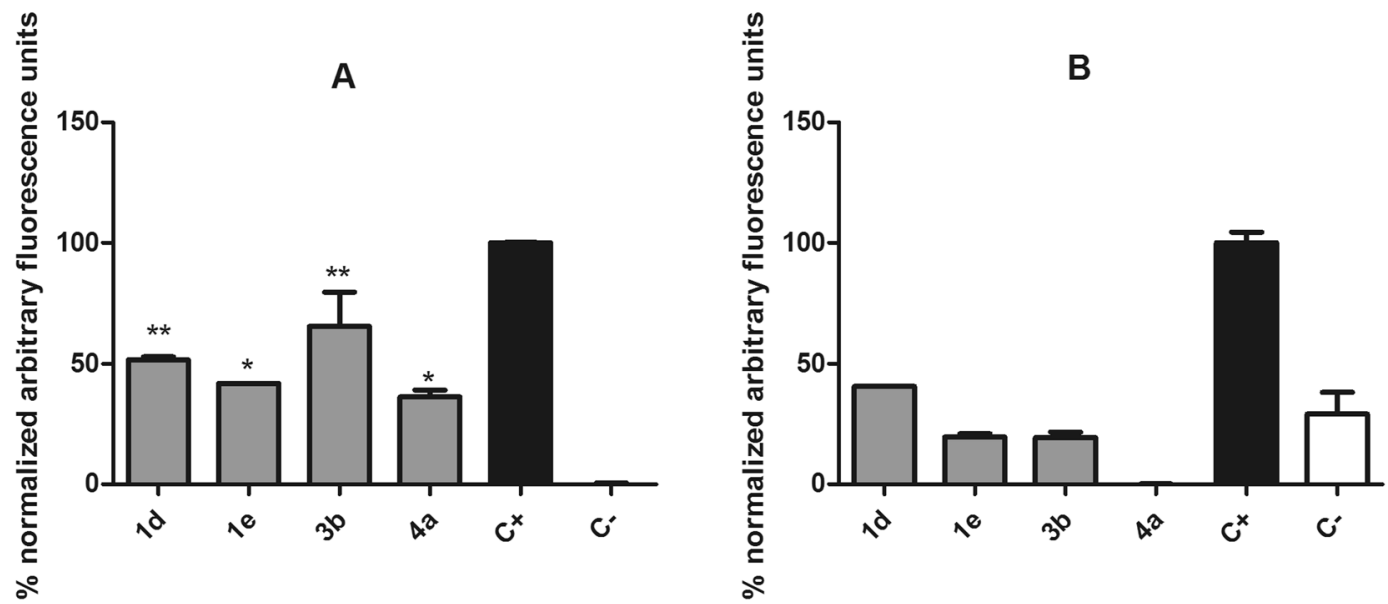

Figure 6. Evaluation of reactive oxygen species (ROS) generation in T. cruzi trypomastigotes treated with compounds $\mathbf{1 d}, \mathbf{1 e}, \mathbf{3 b}$ and $\mathbf{4 a}$ for $1 \mathrm{~h}(\mathbf{A})$ and $2 \mathrm{~h}(\mathbf{B})$. The $\mathrm{H}_{2}$ DCFDA fluorescent probe was analyzed spectrofluorimetrically (excitation $485 \mathrm{~nm}$ and emission $520 \mathrm{~nm}$ ). Untreated trypomastigotes and treated with azide $(10 \mathrm{mM})$ were used to achieve minimal and maximal ROS production, negative $(\mathrm{C}-)$ and positive control $(\mathrm{C}+)$, respectively. One representative experiment of two assays is shown. $* * \mathrm{p}<0.001$.

induced no significant alterations in ATP levels (Fig. 7). The stability of ATP levels and mitochondrial membrane potential is a requisite for a normal cell functioning ${ }^{32}$. Mitochondria is a single organelle in trypanosomatids and is directly involved in redox status of the parasite ${ }^{33}$ and plays a central role in energy metabolism, being the site of the oxidative phosphorylation that drives the ATP synthesis and represent the main sources of ROS. Additionally, it participates in the nutrient oxidation, calcium homeostasis and apoptosis ${ }^{34}$. With the exception of compound 4a, the compounds induced a mitochondrial hyperpolarization, but with no statistical significance (Fig. 8), suggesting that they probably lead to alterations in the respiratory chain.

Permeability of licarin A and analogues in PAMPA models. To estimate the intestinal absorption and permeability of the semi-synthetic and simplified analogues of licarin A through the BBB, two PAMPA models were employed, as summarized in Table 1. Accordingly, the semi-synthetic derivatives 1a-1e present low intestinal permeability since their Papp values are lower than $1.0 \times 10^{-6} \mathrm{~cm} / \mathrm{s}$, suggesting that the excessive lipophilicity may impair the oral bioavailability of these compounds. This result is in agreement with the low permeability observed in the BBB model for $\mathbf{1 b}-\mathbf{1 e}$. The Lipinski's rule-of-five ${ }^{35}$ defines that compounds with high molecular mass $(>500 \mathrm{Da})$ and high $\log \mathrm{P}(>5)$ may present low oral bioavailability, so the compounds fulfil the rule-of-five. However, they already present Clog $\mathrm{P}$ values close to 5 , and further modifications would raise this value over 5 . The rule-of-three ${ }^{36}$ is used as guide for designing compounds identified from screening tests because it considers that medicinal chemists will modify the compound, increasing the molecular weight and the lipophilicity. Accordingly, the threshold of rule-of-three is more rigid, limiting the log P until 3 and molecular mass until 300 and thus compound 1 do not fulfil this criterion. Considering this point, the simplified compounds 2-5 are smaller, less lipophilic compounds that fulfil the rule-of-three and, as can be noted in the results 
A

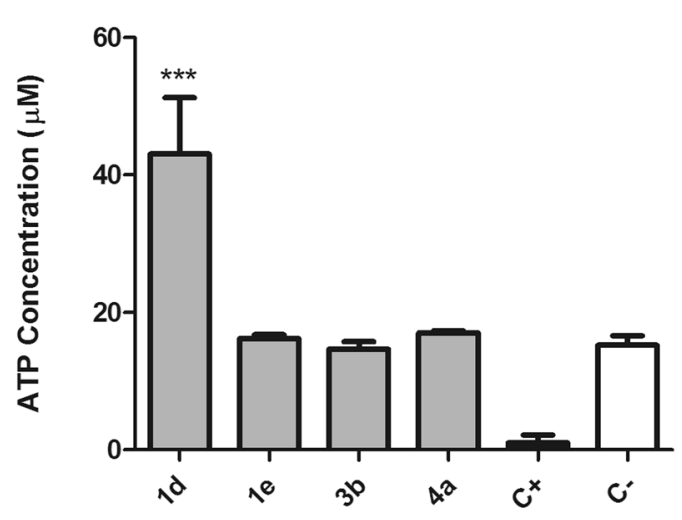

B

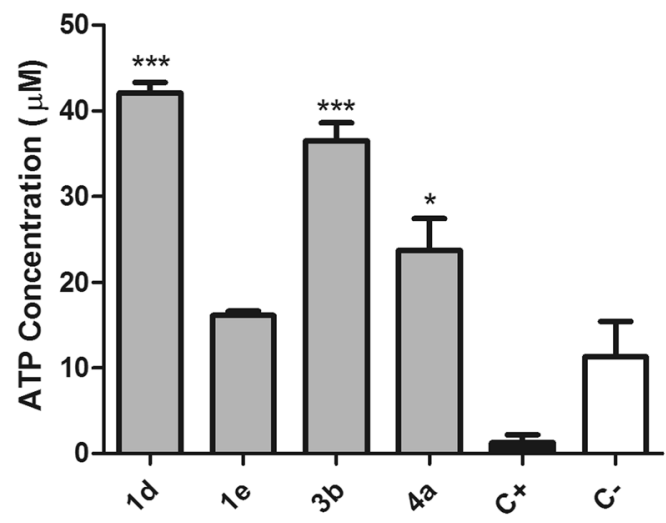

Figure 7. Evaluation of ATP production in T. cruzi trypomastigotes treated by $1 \mathrm{~h}(\mathbf{A})$ and $2 \mathrm{~h}(\mathbf{B})$ with the compounds $\mathbf{1 d}, \mathbf{1 e}, \mathbf{3} \mathbf{b}$ and $\mathbf{4 a}$ ( $\mathrm{IC}_{50}$ values). Untreated trypomastigotes, negative control $(\mathrm{C}-)$ and treated with CCCP $(100 \mu \mathrm{M})$, positive control $(\mathrm{C}+)$ were used as controls of minimal and maximal depolarization. One representative experiment of two assays is shown. $* * * \mathrm{p}<0.0001$.

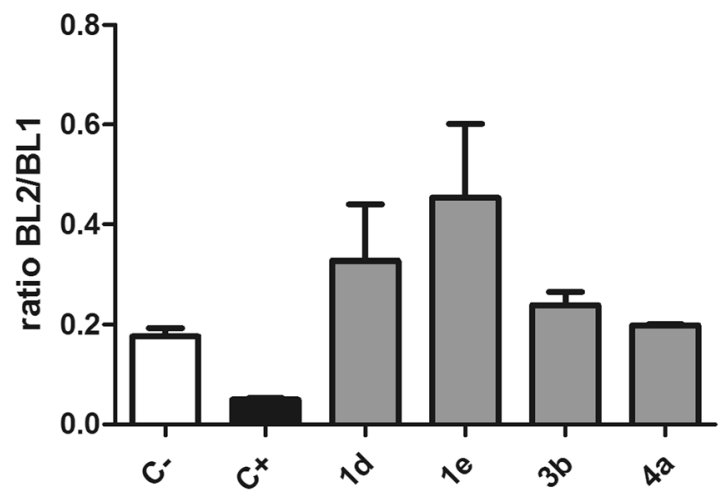

Figure 8. Mitochondrial membrane potential analysis in T. cruzi trypomastigotes treated with compounds $\mathbf{1 d}, \mathbf{1 e}, \mathbf{3 b}$ and $\mathbf{4 a}$ for two hours labeled with $\mathrm{JC}-1$ probe $(0.2 \mu \mathrm{M})$. The fluorescence was measured in a flow cytometer (ATTUNE). Minimum (untreated - negative control, C-) and maximum (treated with CCCP$100 \mu \mathrm{g} / \mathrm{mL}$ - positive control, $\mathrm{C}+$ ) alterations in the mitochondrial membrane potential were obtained. Fluorescence was quantified by calculating the ratio between the channels BL2/BL1. One representative experiment of two assays is shown.

from Table 1, these compounds presented increased permeability through GIT and limited permeability through BBB. This data suggests that these compounds present better drug-likeness, improved oral bioavailability and less CNS-related off-target toxicity. Therefore, the most promising was the compound $\mathbf{4}$, which presented adequate permeability on GIT model, and did not seem to cross the BBB, reinforcing its promising pharmacological profile. In addition, the PAMPA-GIT model also estimated that compound 4 has a protein plasma binding percentage lower than $90 \%$ ( part, lipophilic compounds such as $\mathbf{2 a}, \mathbf{2 b}, \mathbf{4 a}, \mathbf{4 b}$ and $\mathbf{5}$ seem to have a plasma protein binding percentage higher than $90 \%$ (Table 1) which can impair the bloodstream availability of the free compound and their distribution into the tissues, where the amastigotes are present, compromising drug efficacy.

\section{Conclusions}

In summary, although the semi-synthetic derivatives of licarin A showed activity against T. cruzi, their low drug-likeness limit their exploitation as prototypes for designing novel compounds with improved pharmacological profile. Therefore, the molecular simplification approach increased the lead-likeness of the set and generated fewer complex compounds with interesting antiparasitic activity that can be considered better prototypes for further modifications, aiming improved activity allied with promising ADME profile.

\section{Methods}

General experimental procedures. ${ }^{1} \mathrm{H}$ and ${ }^{13} \mathrm{C}$ NMR spectra were recorded on a Bruker Advance 300, operating at $300 \mathrm{MHz}$ for ${ }^{1} \mathrm{H}$ and $75 \mathrm{MHz}$ for ${ }^{13} \mathrm{C}$, using $\mathrm{CDCl}_{3}$ as solvent and TMS as internal standard. Chemical shifts $(\delta)$ are given in ppm and the coupling constants $(J)$ are presented in Hz. HRESIMS spectra were measured on a Bruker Daltonics MicroTOF QII spectrometer. Starting materials were acquired from commercial suppliers 
with purity higher than $98 \%$ and used without further processing. Claisen rearrangements were performed on a Discovery microwave reactor (CEM Inc.) using a sealed reaction vial with a high-pressure accessory. Column chromatography (CC) procedures were performed using silica gel 60 while progress of the reactions was monitored through TLC in silica gel plates with fluorescence indicator and visualized at $254 \mathrm{~nm}$.

Plant material. Fresh leaves of Nectandra oppositifolia were collected at Artur Nogueira city, São Paulo State, Brazil $\left(22^{\circ} 30^{\prime} 57,65^{\prime \prime} \mathrm{S}\right.$ and $\left.47^{\circ} 10^{\prime} 50,11^{\prime \prime} \mathrm{W}\right)$ in April/2016. The plant material was identified by Prof. MSc. Guilherme M. Antar. A voucher specimen was compared with that under code SPF225339, deposited in the Herbarium of Institute of Biosciences, University of São Paulo, SP, Brazil.

Isolation of licarin A from N. oppositifolia. After being dried and powdered, the leaves of N. oppositifolia $(332 \mathrm{~g})$ were extracted using $n$-hexane $(6 \times 1 \mathrm{~L})$ at room temperature. After evaporation of the solvent at reduced pressure, $32 \mathrm{~g}$ of crude $n$-hexane extract were obtained. Part of this material $(20 \mathrm{~g})$ was chromatographed over a silica gel column eluted with $n$-hexane containing increasing amounts of EtOAc to afford five groups (I-V). Part of the group IV $(3280 \mathrm{mg})$ was chromatographed over a silica gel column eluted with mixtures of $n$-hexane:EtOAc $(8: 2,7: 3,1: 1$, and $2: 8)$ to afford $1280 \mathrm{mg}$ of licarin $\mathrm{A}$.

Licarin A (1). ${ }^{1} \mathrm{H}$ NMR $\left(\mathrm{CDCl}_{3}\right), \delta 6.97(\mathrm{~d}, J=1.4 \mathrm{~Hz}, \mathrm{H}-2), 6.92(\mathrm{dd}, J=7.8$ and $1.4 \mathrm{~Hz}, \mathrm{H}-6), 6.91(\mathrm{~d}$, $J=7.8 \mathrm{~Hz}, \mathrm{H}-5), 6.79\left(\mathrm{br} \mathrm{s}, \mathrm{H}-2^{\prime}\right), 6.77\left(\mathrm{br} \mathrm{s}, \mathrm{H}-6^{\prime}\right), 6.36\left(\mathrm{dd}, J=15.7\right.$ and $\left.1.6 \mathrm{~Hz}, \mathrm{H}-7^{\prime}\right), 6.11(\mathrm{dq}, J=15.7$ and $\left.6.6 \mathrm{~Hz}, \mathrm{H}-8^{\prime}\right), 5.63(\mathrm{~s}, \mathrm{OH}), 5.11(\mathrm{~d}, J=9.4 \mathrm{~Hz}, \mathrm{H}-7), 3.90\left(\mathrm{~s}, \mathrm{OCH}_{3}\right), 3.89\left(\mathrm{~s}, \mathrm{OCH}_{3}\right), 3.45(\mathrm{dq}, J=9.4$ and $6.8 \mathrm{~Hz}$, $\mathrm{H}-8), 1.87\left(\mathrm{dd}, J=6.6\right.$ and $\left.1.6 \mathrm{~Hz}, \mathrm{H}-9^{\prime}\right), 1.38(\mathrm{~d}, J=6.8 \mathrm{~Hz}, \mathrm{H}-9) .{ }^{13} \mathrm{C} \mathrm{NMR}\left(\mathrm{CDCl}_{3}\right), \delta 146.7(\mathrm{C}-3), 146.6\left(\mathrm{C}-4^{\prime}\right)$,

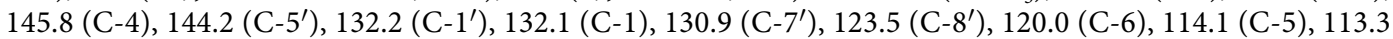
$\left(\mathrm{C}-2^{\prime}\right), 113.2\left(\mathrm{C}-3^{\prime}\right), 109.3\left(\mathrm{C}-6^{\prime}\right), 108.9(\mathrm{C}-2), 93.8(\mathrm{C}-7), 56.1\left(\mathrm{OCH}_{3}\right), 56.0\left(\mathrm{OCH}_{3}\right), 45.6(\mathrm{C}-8), 18.4\left(\mathrm{C}-9^{\prime}\right), 17.6$ (C-9). HRESIMS $m / z 327.1592[\mathrm{M}+\mathrm{H}]^{+}$(calcd for $\left.\mathrm{C}_{20} \mathrm{H}_{23} \mathrm{O}_{4} 327.1596\right)$.

Molecular simplification of licarin A and derivatives. The molecular simplification approach was employed to licarin A and semi-synthetic derivatives considering that licarin A is comprised by a vanillin-like moiety (represented in red - part A, in Fig. 3) and an isoeugenol-like moiety (represented in blue - part B, in Fig. 3). The parent licarin molecule was then broke apart to generate the vanillin analogues ( 2 and $\mathbf{3})$ and the isoeugenol analogues (4 and 5), with the same substitution pattern from the semi-synthetic derivatives (a 4-methoxy; b - 4-acetoxy; c - 4-allyloxi; d - 5-allyl). It must be in mind that simplification strategy is very intuitive and based on a medicinal chemist's hypothesis from the pharmacophore units of the parent molecule, that is usually supported by preliminary SAR data ${ }^{22,23}$, as those obtained with the derivatives of licarin A.

General procedure for the preparation of compounds 1a-5a. Using individual flasks containing licarin A (1), vanillin (2), vanillyl alcohol (3), isoeugenol (4), or eugenol (5), two equivalents of $\mathrm{K}_{2} \mathrm{CO}_{3}$, two equivalents of methyl iodide and $10 \mathrm{~mL}$ of acetone were added. The reaction mixtures were stirred under reflux for $7 \mathrm{~h}$, and thus the volatiles were evaporated under reduced pressure. The residue was taken up in $\mathrm{CH}_{2} \mathrm{Cl}_{2}$ and washed with $\mathrm{H}_{2} \mathrm{O}(2 \times 25 \mathrm{~mL})$. The organic layers were separated, dried over anhydrous $\mathrm{Na}_{2} \mathrm{SO}_{4}$ and the solvent was evaporated under reduced pressure. Crude products were purified through silica gel column chromatography using $n$-hexane:EtOAc (9:1) as eluent.

(2S,3 S)-2-(3,4-dimethoxyphenyl)-7-methoxy-3-methyl-5-[(E)-prop-1-enyl]-2,3-dihydrobenzo-furan (1a): $220 \mathrm{mg}$ of compound $\mathbf{1}$ yielded $73 \%$ of $\mathbf{1 a}$ as a white amorphous solid. ${ }^{1} \mathrm{H}$ NMR $\left(\mathrm{CDCl}_{3}\right) \delta 7.01(\mathrm{~d}, J=1.7 \mathrm{~Hz}$, $\mathrm{H}-5) ; 7.00(\mathrm{dd}, J=6.0$ and $1.8 \mathrm{~Hz}, \mathrm{H}-6), 6.95(\mathrm{~d}, J=1.9 \mathrm{~Hz}, \mathrm{H}-2), 6.86\left(\mathrm{~d}, J=8.2 \mathrm{~Hz}, \mathrm{H}-6^{\prime}\right), 6.80(\mathrm{~d}, J=6.3 \mathrm{~Hz}$, $\left.\mathrm{H}-2^{\prime}\right), 6.36\left(\mathrm{dd}, J=15.6\right.$ and $\left.1.3 \mathrm{~Hz}, \mathrm{H}-7^{\prime}\right), 6.10\left(\mathrm{dq}, J=15.6\right.$ and $\left.6.5 \mathrm{~Hz}, \mathrm{H}-8^{\prime}\right), 5.11(\mathrm{~d}, J=9.4 \mathrm{~Hz}, \mathrm{H}-7), 3.91(\mathrm{~s}$, $\left.\mathrm{OCH}_{3}\right), 3.90\left(\mathrm{~s}, \mathrm{OCH}_{3}\right), 3.88\left(\mathrm{~s}, \mathrm{OCH}_{3}\right), 3.45(\mathrm{dd}, J=9.2$ and $6.8 \mathrm{~Hz}, \mathrm{H}-8), 1.86\left(\mathrm{dd}, J=6.6\right.$ and $\left.1.3 \mathrm{~Hz}, \mathrm{H}-9^{\prime}\right), 1.38$ $(\mathrm{d}, J=6.8 \mathrm{~Hz}, \mathrm{H}-9) .{ }^{13} \mathrm{C}$ NMR $\left(\mathrm{CDCl}_{3}\right) \delta 149.1(\mathrm{C}-4), 149.0\left(\mathrm{C}-5^{\prime}\right), 146.6\left(\mathrm{C}-6^{\prime}\right), 144.2(\mathrm{C}-3), 133.3\left(\mathrm{C}-4^{\prime}\right), 132.6$ (C-6), $132.2\left(\mathrm{C}-6^{\prime}\right), 130.9\left({\mathrm{C}-7^{\prime}}^{\prime}\right), 123.5\left(\mathrm{C}-8^{\prime}\right), 119.2(\mathrm{C}-1), 113.3(\mathrm{C}-2), 110.8\left(\mathrm{C}-3^{\prime}\right), 109.5\left(\mathrm{C}-1^{\prime}\right), 108.9(\mathrm{C}-5)$, 93.6 (C-7), $55.9\left(\mathrm{OCH}_{3}\right), 55.8\left(\mathrm{OCH}_{3}\right), 55.9\left(\mathrm{OCH}_{3}\right), 45.5(\mathrm{C}-8), 18.4\left(\mathrm{C}-9^{\prime}\right), 17.6(\mathrm{C}-9)$. HRESIMS $m / z 341.1750$ $[\mathrm{M}+\mathrm{H}]^{+}$(calcd. for $\left.\mathrm{C}_{21} \mathrm{H}_{25} \mathrm{O}_{4} 341.1753\right)$.

3,4-dimethoxybenzaldehyde (2a): $250 \mathrm{mg}$ of compound $\mathbf{2}$ yielded $70 \%$ of $\mathbf{2 a}$ as white crystals. ${ }^{1} \mathrm{H}$ NMR $\left(\mathrm{CDCl}_{3}\right)$ $\delta 9.61(\mathrm{~s}, \mathrm{H}-7), 7.44(\mathrm{dd}, J=8.0$ and $1.8 \mathrm{~Hz}, \mathrm{H}-6), 7.33(\mathrm{~s}, J=1.8 \mathrm{~Hz}, \mathrm{H}-2), 7.18(\mathrm{~d}, J=8.0 \mathrm{~Hz}, \mathrm{H}-5), 3.87\left(\mathrm{~s}, \mathrm{OCH}_{3}\right)$, $3.83\left(\mathrm{~s}, \mathrm{OCH}_{3}\right) .{ }^{13} \mathrm{C} \mathrm{NMR}\left(\mathrm{CDCl}_{3}\right) \delta 191.0(\mathrm{C}-7), 155.8$ (C-4), 150.7 (C-3), $130.4(\mathrm{C}-1), 127.1(\mathrm{C}-6), 115.4(\mathrm{C}-5)$, $109.9(\mathrm{C}-2), 56.1\left(\mathrm{OCH}_{3}\right), 56.0\left(\mathrm{OCH}_{3}\right)$. HRESIMS $m / z 167.0713[\mathrm{M}+\mathrm{H}]^{+}$(calcd. for $\left.\mathrm{C}_{9} \mathrm{H}_{11} \mathrm{O}_{3} 167.0708\right)$.

(3,4-dimethoxyphenyl)methanol (3a): $270 \mathrm{mg}$ of compound 3 yielded $66 \%$ of $3 \mathbf{a}$ as yellowish liquid. ${ }^{1} \mathrm{H}$ NMR $\left(\mathrm{CDCl}_{3}\right) \delta 6.86$ (br s, H-6 and H-5), $6.83(\mathrm{~s}, \mathrm{H}-2), 3.82\left(\mathrm{~s}, \mathrm{OCH}_{3}\right) .{ }^{13} \mathrm{C} \mathrm{NMR}\left(\mathrm{CDCl}_{3}\right) \delta 191.0(\mathrm{C}-7), 155.8(\mathrm{C}-4)$, 150.7 (C-3), 130.4 (C-1), 127.1 (C-6), 115.4 (C-5), 109.9 (C-2), $56.1\left(\mathrm{OCH}_{3}\right), 55.9\left(\mathrm{OCH}_{3}\right) . \mathrm{HRESIMS} \mathrm{m} / z$ $169.0870[\mathrm{M}+\mathrm{H}]^{+}$(calcd. for $\left.\mathrm{C}_{9} \mathrm{H}_{13} \mathrm{O}_{3} 169.0865\right)$.

1,2-dimethoxy-4-[(E)-prop-1-enyl]benzene (4a): $280 \mathrm{mg}$ of compound 4 yielded $59 \%$ of $4 \mathbf{a}$ as yellowish liquid. ${ }^{1} \mathrm{H} \mathrm{NMR}\left(\mathrm{CDCl}_{3}\right) \delta 6.65(\mathrm{dd}, J=8.0 \mathrm{~Hz}, \mathrm{H}-6), 6.48(\mathrm{~d}, J=8.0 \mathrm{~Hz}, \mathrm{H}-2), 6.44(\mathrm{dd}, J=15.1 \mathrm{and} 0.8 \mathrm{~Hz}, \mathrm{H}-7), 6.30$ (d, $J=8.0$ and $1.9 \mathrm{~Hz}, \mathrm{H}-6), 6.00-5.88(\mathrm{~m}, \mathrm{H}-8), 3.85\left(\mathrm{~s}, \mathrm{OCH}_{3}\right), 3.83\left(\mathrm{~s}, \mathrm{OCH}_{3}\right), 1.97(\mathrm{dd}, J=6.3$ and $0.8 \mathrm{~Hz}, \mathrm{H}-9)$. ${ }^{13} \mathrm{C} \mathrm{NMR}\left(\mathrm{CDCl}_{3}\right) \delta 153.8(\mathrm{C}-2), 150.7$ (C-1), 150.4 (C-6), 137.1 (C-8), $135.4(\mathrm{C}-4), 115.9(\mathrm{C}-9), 111.7$ (C-5), $107.4(\mathrm{C}-3), 56.1(\mathrm{OCH} 3), 56.0\left(\mathrm{OCH}_{3}\right), 39.9(\mathrm{C}-7)$. HRESIMS $m / z 179.1069[\mathrm{M}+\mathrm{H}]^{+}\left(\right.$calcd. for $\mathrm{C}_{11} \mathrm{H}_{15} \mathrm{O}_{2}$ 179.1072).

4-allyl-1,2-dimethoxy-benzene (5a): $290 \mathrm{mg}$ of compound $\mathbf{5}$ yielded $65 \%$ of $\mathbf{5 a}$ as citrine liquid. ${ }^{1} \mathrm{H}$ NMR $\left(\mathrm{CDCl}_{3}\right) \delta 6.68(\mathrm{dd}, J=8.0$ and $1.9 \mathrm{~Hz}, \mathrm{H}-6), 6.45(\mathrm{~d}, J=1.9 \mathrm{~Hz}, \mathrm{H}-2), 6.30(\mathrm{~d}, J=1.9 \mathrm{~Hz}, \mathrm{H}-5), 6.04-5.83(\mathrm{~m}$, $\mathrm{H}-8), 5.10-4.99$ (m, H-9), $3.85\left(\mathrm{~s}, \mathrm{OCH}_{3}\right), 3.83\left(\mathrm{~s}, \mathrm{OCH}_{3}\right), 3.24-3.22(\mathrm{~m}, \mathrm{H}-7) .{ }^{13} \mathrm{C} \mathrm{NMR}\left(\mathrm{CDCl}_{3}\right) \delta 153.8(\mathrm{C}-2)$, 150.7 (C-1), 150.4 (C-6), 137.1 (C-8), 135.4 (C-4), 115.9 (C-9), 111.7 (C-5), 107.4 (C-3), $56.1\left(\mathrm{OCH}_{3}\right), 56.0$ $\left(\mathrm{OCH}_{3}\right), 39.9(\mathrm{C}-7)$. HRESIMS $m / z 179.1070[\mathrm{M}+\mathrm{H}]^{+}$(calcd. for $\mathrm{C}_{11} \mathrm{H}_{15} \mathrm{O}_{2}$ 179.1072). 
General procedure for the preparation of compounds $\mathbf{1 b} \mathbf{- 5} \mathbf{b}$. Using individual flasks containing compounds 1-5, one equivalent of triethylamine, two equivalents of acetyl chloride and $5 \mathrm{~mL}$ of $\mathrm{CH}_{2} \mathrm{Cl}_{2}$ were added. The reaction mixtures were stirred under an ice bath for $4 \mathrm{~h}$, when $\mathrm{NaHCO}_{3}$ solution $(10 \%)$ was added for neutralization of acids. The organic layers were separated, washed with $\mathrm{H}_{2} \mathrm{O}(2 \times 25 \mathrm{~mL})$, dried over anhydrous $\mathrm{Na}_{2} \mathrm{SO}_{4}$ and evaporated under reduced pressure. Crude products were purified through silica gel column chromatography using $n$-hexane:EtOAc (9:1) as eluent.

[2-methoxy-4-[(2S,3S)-7-methoxy-3-methyl-5-[(E)-prop-1-enyl]-2,3-dihydrobenzofuran-2-yl]phenyl] acetate $(\mathbf{1 b}): 350 \mathrm{mg}$ of compound $\mathbf{1}$ yielded $27 \%$ of $\mathbf{1 b}$ as white amorphous solid. ${ }^{1} \mathrm{H} \mathrm{NMR}\left(\mathrm{CDCl}_{3}\right) \delta 7.00\left(\mathrm{br} \mathrm{s}, \mathrm{H}-6^{\prime}\right)$, 6.98 (br s, H-2'), 6.88 (br s, H-2), 6.80 (br s, H-6), 6.78 (br s, H-5), 6.36 (dd, $J=15.7$ and 1.5 Hz, H-7'), 6.10 (dq, $J=15.7$ and $\left.6.6 \mathrm{~Hz}, \mathrm{H}-8^{\prime}\right), 5.11(\mathrm{~d}, J=9.2 \mathrm{~Hz}, \mathrm{H}-7), 3.46(\mathrm{dd}, J=9.2$ and $6.8 \mathrm{~Hz}, \mathrm{H}-8), 1.87(\mathrm{dd}, J=6.6 \mathrm{and} 1.5 \mathrm{~Hz}$, $\left.\mathrm{H}-9^{\prime}\right), 1.41(\mathrm{~d}, J=6.8 \mathrm{~Hz}, \mathrm{H}-9), 3.90\left(\mathrm{~s}, \mathrm{OCH}_{3}\right), 3.88\left(\mathrm{~s}, \mathrm{OCH}_{3}\right), 2.31\left(\mathrm{~s}, \mathrm{CH}_{3}\right) .{ }^{13} \mathrm{C} \mathrm{NMR}\left(\mathrm{CDCl}_{3}\right) \delta 169.0(\mathrm{C}=\mathrm{O})$, $151.2\left(\mathrm{C}-5^{\prime}\right), 146.5(\mathrm{C}-4), 144.1\left(\mathrm{C}-6^{\prime}\right), 139.6(\mathrm{C}-3), 139.3\left(\mathrm{C}-4^{\prime}\right), 133.0(\mathrm{C}-6), 132.4\left(\mathrm{C}-6^{\prime}\right), 130.9\left(\mathrm{C}-7^{\prime}\right), 123.6$ $\left(\mathrm{C}-8^{\prime}\right), 122.7(\mathrm{C}-1), 118.7(\mathrm{C}-2), 113.4\left(\mathrm{C}-3^{\prime}\right), 110.3\left(\mathrm{C}-1^{\prime}\right), 109.3(\mathrm{C}-5), 93.1(\mathrm{C}-7), 55.9\left(\mathrm{OCH}_{3}\right), 45.8(\mathrm{C}-8), 17.9$ (C-9), $20.7\left(\mathrm{CH}_{3}\right), 18.4\left(\mathrm{C}-9^{\prime}\right)$, HRESIMS $m / z 369.1707[\mathrm{M}+\mathrm{H}]^{+}$(calcd. for $\left.\mathrm{C}_{22} \mathrm{H}_{25} \mathrm{O}_{5} 369.1702\right)$.

(4-formyl-2-methoxy-phenyl) acetate (2b): $380 \mathrm{mg}$ of compound $\mathbf{2}$ yielded $38 \%$ of $\mathbf{2 b}$ as white crystals. ${ }^{1} \mathrm{H}$ NMR $\left(\mathrm{CDCl}_{3}\right) \delta 9.90(\mathrm{~s}, \mathrm{H}-7), 7.46(\mathrm{~d}, J=1.8 \mathrm{~Hz}, \mathrm{H}-2), 7.44(\mathrm{dd}, J=8.0$ and $1.8 \mathrm{~Hz}, \mathrm{H}-6), 7.20(\mathrm{~d}, J=8.0 \mathrm{~Hz}, \mathrm{H}-5), 3.82$ $\left(\mathrm{s}, \mathrm{OCH}_{3}\right), 2.29\left(\mathrm{~s}, \mathrm{CH}_{3}\right) .{ }^{13} \mathrm{C}$ NMR $\left(\mathrm{CDCl}_{3}\right) \delta 191.0(\mathrm{C}-7), 169.0(\mathrm{C}=\mathrm{O}), 151.5(\mathrm{C}-3), 140.7(\mathrm{C}-4), 125.9(\mathrm{C}-1)$, $122.8(\mathrm{C}-5), 121.1(\mathrm{C}-6), 113.6(\mathrm{C}-2), 55.8\left(\mathrm{OCH}_{3}\right), 20.3\left(\mathrm{CH}_{3}\right)$. HRESIMS $m / z 195.0663[\mathrm{M}+\mathrm{H}]^{+}$(calcd. for $\mathrm{C}_{10} \mathrm{H}_{11} \mathrm{O}_{5}$ 195.0657).

[4-(hydroxymethyl)-2-methoxy-phenyl] acetate (3b): $350 \mathrm{mg}$ of compound $\mathbf{3}$ yielded $27 \%$ of $\mathbf{3 b}$ as yellow liquid. ${ }^{1} \mathrm{H} \mathrm{NMR}\left(\mathrm{CDCl}_{3}\right) \delta 7.02$ (br s, H-5), 7.00 (br s, H-6), 6.83 (br s, H-2), 4.73 (s, H-7) $3.81\left(\mathrm{~s}, \mathrm{OCH}_{3}\right) 2.28\left(\mathrm{~s}, \mathrm{CH}_{3}\right)$. ${ }^{13} \mathrm{C} \mathrm{NMR}\left(\mathrm{CDCl}_{3}\right) \delta 191.0(\mathrm{C}-7), 169.1(\mathrm{C}=\mathrm{O}), 152.2(\mathrm{C}-3), 147.7$ (C-4), 134.7 (C-1), 125.1 (C-5), $124.4(\mathrm{C}-6)$, $112.9(\mathrm{C}-2), 55.6\left(\mathrm{OCH}_{3}\right), 20.1\left(\mathrm{CH}_{3}\right)$. HRESIMS $m / z$ 197.0810 $[\mathrm{M}+\mathrm{H}]^{+}$(calcd. for $\left.\mathrm{C}_{10} \mathrm{H}_{13} \mathrm{O}_{4} 197.0814\right)$.

[2-methoxy-4-[(E)-prop-1-enyl]phenyl] acetate (4b): $380 \mathrm{mg}$ of compound 4 yielded $67 \%$ of $\mathbf{4 b}$ as yellow liquid. ${ }^{1} \mathrm{H}$ NMR $\left(\mathrm{CDCl}_{3}\right) \delta 6.97(\mathrm{~d}, J=8.0 \mathrm{~Hz}, \mathrm{H}-5), 6.92(\mathrm{~d}, J=8.0 \mathrm{~Hz}, \mathrm{H}-6), 6.91$ (br s, H-2), $6.48(\mathrm{dd}, J=15.1 \mathrm{~Hz}$, $\mathrm{H}-7), 6.25-6.18(\mathrm{~m}, \mathrm{H}-8), 3.85\left(\mathrm{~s}, \mathrm{OCH}_{3}\right), 2.28\left(\mathrm{~s}, \mathrm{CH}_{3}\right), 1.85(3 \mathrm{H}, \mathrm{dd}, J=6.0$ and $0.8 \mathrm{~Hz}, \mathrm{H}-9) .{ }^{13} \mathrm{C} \mathrm{NMR}\left(\mathrm{CDCl}_{3}\right)$ $\delta 169.0(\mathrm{C}=\mathrm{O}), 151.5(\mathrm{C}-3), 141.1(\mathrm{C}-4), 136.5(\mathrm{C}-1), 130.5(\mathrm{C}-7), 124.4(\mathrm{C}-5), 124.0(\mathrm{C}-8), 121.9(\mathrm{C}-6), 55.8$ $\left(\mathrm{OCH}_{3}\right), 20.1\left(\mathrm{CH}_{3}\right), 18.8(\mathrm{C}-9)$. HRESIMS $m / z 207.1018[\mathrm{M}+\mathrm{H}]^{+}\left(\right.$calcd. for $\left.\mathrm{C}_{12} \mathrm{H}_{15} \mathrm{O}_{3} 207.1021\right)$.

(4-allyl-2-methoxy-phenyl) acetate (5b): $380 \mathrm{mg}$ compound 5 yielded $69 \%$ of $\mathbf{5 b}$ as yellow liquid. ${ }^{1} \mathrm{H}$ NMR $\left(\mathrm{CDCl}_{3}\right) \delta 7.06(\mathrm{dd}, J=8.0$ and $2.0 \mathrm{~Hz}, \mathrm{H}-6), 7.01(\mathrm{~d}, J=8.0 \mathrm{~Hz}, \mathrm{H}-5), 6.98(\mathrm{~d}, J=2.0 \mathrm{~Hz}, \mathrm{H}-2), 6.22-6.15(\mathrm{~m}$, $\mathrm{H}-8), 5.10-5.02(\mathrm{~m}, \mathrm{H}-9), 3.80\left(\mathrm{~s}, \mathrm{OCH}_{3}\right), 3.33(\mathrm{~d}, J=6.2 \mathrm{~Hz}, \mathrm{H}-7), 2.28\left(3 \mathrm{H}, \mathrm{s}, \mathrm{CH}_{3}\right) .{ }^{13} \mathrm{C} \mathrm{NMR}\left(\mathrm{CDCl}_{3}\right) \delta 169.4$ $(\mathrm{C}=\mathrm{O}), 151.8$ (C-3), 138.7 (C-4), 137.4 (C-1), 136.1 (C-8), 122.4 (C-5), $121.9(\mathrm{C}-6), 115.7(\mathrm{C}-9), 55.8\left(\mathrm{OCH}_{3}\right)$, $39.8(\mathrm{C}-7), 20.5\left(\mathrm{CH}_{3}\right)$. HRESIMS $m / z 207.1020[\mathrm{M}+\mathrm{H}]^{+}\left(\right.$calcd. for $\left.\mathrm{C}_{12} \mathrm{H}_{15} \mathrm{O}_{3} 207.1021\right)$.

General procedure for the preparation of compounds $\mathbf{1 c}-\mathbf{5 c}$. Using individual flasks containing compounds 1-5, two equivalents of $\mathrm{K}_{2} \mathrm{CO}_{3}$, two equivalents of allyl bromide and $15 \mathrm{~mL}$ of acetone were added. The reaction mixtures were stirred under reflux for $19 \mathrm{~h}$, and thus the volatiles were evaporated under reduced pressure. The residues were dissolved in $\mathrm{CH}_{2} \mathrm{Cl}_{2}$ and washed with $\mathrm{H}_{2} \mathrm{O}(2 \times 25 \mathrm{~mL})$. The organic layers were separated, dried over anhydrous $\mathrm{Na}_{2} \mathrm{SO}_{4}$ and evaporated under reduced pressure. Crude products were purified through silica gel column chromatography using $n$-hexane:EtOAc $(9: 1)$ as eluent.

(2S,3S)-2-(4-allyloxy-3-methoxy-phenyl)-7-methoxy-3-methyl-5-[(E)-prop-1-enyl]-2,3-dihydrobenzofuran (1c): $600 \mathrm{mg}$ of compound 1 yielded $73 \%$ of $1 \mathrm{c}$ as white amorphous solid. ${ }^{1} \mathrm{H} \mathrm{NMR}\left(\mathrm{CDCl}_{3}\right) \delta 6.99(\mathrm{~d}, J=8.2 \mathrm{~Hz}$, $\mathrm{H}-5), 6.93(\mathrm{~d}, J=1.9 \mathrm{~Hz}, \mathrm{H}-2), 6.92(\mathrm{dd}, J=8.2$ and $1.9 \mathrm{~Hz}, \mathrm{H}-6), 6.84\left(\mathrm{~d}, J=1.9 \mathrm{~Hz}, \mathrm{H}-2^{\prime}\right), 6.78(\mathrm{~d}, J=1.9 \mathrm{~Hz}$, $\left.\mathrm{H}-6^{\prime}\right), 6.36\left(\mathrm{dd}, J=15.7\right.$ and $\left.1.5 \mathrm{~Hz}, \mathrm{H}-7^{\prime}\right), 6.09$ (qdd, $J=10.6,7.2$ and $\left.4.8 \mathrm{~Hz}, \mathrm{H}-\beta\right), 6.04-6.16\left(\mathrm{~m}, \mathrm{H}-8^{\prime}\right), 5.39$ $(\mathrm{dd}, J=17.3$ and $1.5 \mathrm{~Hz} ; \mathrm{H}-\gamma), 5.11(\mathrm{~d}, J=9.4 \mathrm{~Hz}, \mathrm{H}-7), 4.61(\mathrm{dt}, J=5.4$ and $1.4 \mathrm{~Hz}, \mathrm{H}-\alpha), 3.86\left(\mathrm{~s}, \mathrm{OCH}_{3}\right), 3.89$ $\left(\mathrm{s}, \mathrm{OCH}_{3}\right), 3.46(\mathrm{dq}, J=13.6$ and $6.8 \mathrm{~Hz} ; \mathrm{H}-8), 1.86\left(\mathrm{dd}, J=6.6\right.$ and $\left.1.3 \mathrm{~Hz}, \mathrm{H}-9{ }^{\prime}\right), 1.38(\mathrm{~d}, J=6.8 \mathrm{~Hz}, \mathrm{H}-9) .{ }^{13} \mathrm{C}$ $\operatorname{NMR}\left(\mathrm{CDCl}_{3}\right) \delta 149.6\left(\mathrm{C}-5^{\prime}\right), 148.1\left(\mathrm{C}-4^{\prime}\right), 146.6\left(\mathrm{C}-6^{\prime}\right), 144.1(\mathrm{C}-3), 133.3(\mathrm{C}-4), 133.2(\mathrm{C}-2), 133.0(\mathrm{C}-6), 132.3$

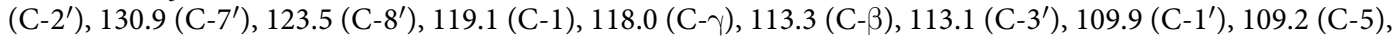
93.6 (C-7), $69.9(\mathrm{C}-\alpha), 55.9\left(\mathrm{OCH}_{3}\right), 45.6(\mathrm{C}-8), 18.4\left(\mathrm{C}-9^{\prime}\right), 17.7(\mathrm{C}-9)$, HRESIMS $m / z 367.1920[\mathrm{M}+\mathrm{H}]^{+}(\mathrm{calcd}$. for $\left.\mathrm{C}_{23} \mathrm{H}_{26} \mathrm{O}_{4} 367.1909\right)$.

4-allyloxy-3-methoxy-benzaldehyde (2c): $700 \mathrm{mg}$ of compound 2 yielded $77 \%$ of $2 \mathrm{c}$ as yellowish liquid. ${ }^{1} \mathrm{H}$ $\operatorname{NMR}\left(\mathrm{CDCl}_{3}\right) \delta 9.88$ (s, H-7), 7.33 (br s, H-2), 7.32 (br s, H-6), 7.02 (br s, H-5), 5.91-5.83 (m, H- $\beta$ ), 5.20-5.18 $(\mathrm{m}, \mathrm{H}-\gamma), 4.61(\mathrm{~d}, \mathrm{~J}=6.2 \mathrm{~Hz}, \mathrm{H}-\alpha), 3.83\left(\mathrm{~s}, \mathrm{OCH}_{3}\right) .{ }^{13} \mathrm{C} \mathrm{NMR}\left(\mathrm{CDCl}_{3}\right) \delta 191.0(\mathrm{C}-7), 153.7(\mathrm{C}-4), 149.0(\mathrm{C}-3)$, 132.7 (C- $\beta$ ), 130.1 (C-1), 124.6 (C-6), 118.2 (C- $\gamma), 108.9$ (C-5), $70.0(\mathrm{C}-\alpha), 55.3\left(\mathrm{OCH}_{3}\right)$. HRESIMS $m / z 193.0860$ $[\mathrm{M}+\mathrm{H}]^{+}$(calcd. for $\mathrm{C}_{11} \mathrm{H}_{13} \mathrm{O}_{3}$ 193.0865).

(4-allyloxy-3-methoxy-phenyl)methanol (3c): $700 \mathrm{mg}$ of compound 3 yielded $81 \%$ of $3 \mathrm{c}$ as white solid. ${ }^{1} \mathrm{H}$ NMR $\left(\mathrm{CDCl}_{3}\right) \delta 6.84$ (br s, H-2), 6.75 (br s, H-6), 6.75 (br s, H-5), 6.08-5.96 (ddt, $J=16.5,10.4$ and 5.2 Hz, H- $\beta$ ), 5.35 (d, $J=16.0 \mathrm{~Hz}, \mathrm{H}-\gamma), 4.51(\mathrm{~d}, J=5.3 \mathrm{H}-\alpha), 3.75\left(\mathrm{~s}, \mathrm{OCH}_{3}\right) .{ }^{13} \mathrm{C}$ NMR $\left(\mathrm{CDCl}_{3}\right) \delta 151.1(\mathrm{C}-4), 150.0(\mathrm{C}-3), 133.5(\mathrm{C}-\beta)$, 121.4 (C-1), 118.2 (C- $\gamma), 117.6$ (C-6), 112.6 (C-2 and C-5), $70.5(\mathrm{C}-\alpha), 65.1(\mathrm{C}-7), 56.1\left(\mathrm{OCH}_{3}\right) . \mathrm{HRESIMS} m / z$ $195.1019[\mathrm{M}+\mathrm{H}]^{+}$(calcd for $\mathrm{C}_{11} \mathrm{H}_{15} \mathrm{O}_{3}$ 195.1021).

1-allyloxy-2-methoxy-4-[(E)-prop-1-enyl]benzene (4c): $800 \mathrm{mg}$ of compound 4 yielded $78 \%$ of $4 \mathrm{c}$ as yellow liquid. ${ }^{1} \mathrm{H}$ NMR $\left(\mathrm{CDCl}_{3}\right) \delta 6.87$ (br s, H-6), 6.79 (br s, H-2), 6.48 (br s, H-5), 6.45 (dd, $J=15.0$ and $1.0 \mathrm{~Hz}, \mathrm{H}-7$ ), $6.22(\mathrm{~m}, \mathrm{H}-8), 5.90-5.85(\mathrm{~m}, \mathrm{H}-\beta), 5.17(\mathrm{~m}, \mathrm{H}-\gamma), 4.60(\mathrm{~d}, J=6.2 \mathrm{~Hz}, \mathrm{H}-\alpha), 3.80\left(\mathrm{~s}, \mathrm{OCH}_{3}\right), 1.77(\mathrm{dd}, J=6.4$ and $0.6 \mathrm{~Hz}, \mathrm{H}-9) .{ }^{13} \mathrm{C}$ NMR $\left(\mathrm{CDCl}_{3}\right) \delta 149.8$ (C-3), 147.1 (C-4), 133.5 (C- $\beta$ ), 132.4 (C-1), 130.3 (C-7), $124.4(\mathrm{C}-8)$, $118.2(\mathrm{C}-\gamma), 119.8(\mathrm{C}-6), 112.1\left(\mathrm{C}-2\right.$ and C-5), $70.0(\mathrm{C}-\alpha), 56.1\left(\mathrm{OCH}_{3}\right), 18.7(\mathrm{C}-9)$. HRESIMS $m / z 205.1224$ $[\mathrm{M}+\mathrm{H}]^{+}$(calcd. for $\left.\mathrm{C}_{13} \mathrm{H}_{17} \mathrm{O}_{2} 205.1229\right)$.

4-allyl-1-allyloxy-2-methoxy-benzene (5c): $800 \mathrm{mg}$ of compound 5 yielded $88 \%$ of $5 \mathrm{c}$ as yellow liquid. ${ }^{1} \mathrm{H} \mathrm{NMR}$ $\left(\mathrm{CDCl}_{3}\right) \delta 6.94$ (d, J=1.8 Hz, H-2), 6.89 (br s, H-5), 6.80 (br s, H-6), 6.23-6.19 (m, H-8), 5.90-5.82 (m, H- 3 ), 5.21-5.12 (m, H-9), $4.60(\mathrm{~d}, J=6.1 \mathrm{~Hz}, \mathrm{H}-\mathrm{\alpha}), 3.80\left(\mathrm{~s}, \mathrm{OCH}_{3}\right), 3.33(\mathrm{~d}, J=6.2 \mathrm{~Hz}, \mathrm{H}-7) .{ }^{13} \mathrm{C} \mathrm{NMR}\left(\mathrm{CDCl}_{3}\right) \delta 149.8$ 
(C-3), 149.5 (C-4), 136.5 (C-8), 133.1 (C-1 and C- $\beta$ ), 122.4 (C-6), 118.2 (C- $\gamma), 115.9$ (C-9), 114.1 (C-2), 112.3 (C-5), $70.5(\mathrm{C}-\alpha), 56.1\left(\mathrm{OCH}_{3}\right), 39.9(\mathrm{C}-7)$. HRESIMS $m / z 205.1226[\mathrm{M}+\mathrm{H}]^{+}\left(\right.$calcd. for $\left.\mathrm{C}_{13} \mathrm{H}_{17} \mathrm{O}_{2} 205.1229\right)$.

General procedure for the preparation of compounds $\mathbf{1 d - 5 d . ~ I n d i v i d u a l ~ f l a s k s ~ c o n t a i n i n g ~ c o m - ~}$ pounds $\mathbf{1 c}-\mathbf{5 c}$ dissolved in $3 \mathrm{~mL}$ of $\mathrm{N}, \mathrm{N}$-dimethylformamide were submitted to microwave irradiation $\left(200^{\circ} \mathrm{C}\right.$, $300 \mathrm{~W}, 300 \mathrm{psi}$ ) for $2 \mathrm{~h}$. After evaporation of the solvent under reduced pressure, the crude products were dissolved in $\mathrm{CH}_{2} \mathrm{Cl}_{2}$ and washed with $\mathrm{H}_{2} \mathrm{O}(2 \times 25 \mathrm{~mL})$. The organic layers were dried over anhydrous $\mathrm{Na}_{2} \mathrm{SO}_{4}$ and evaporated under reduced pressure. Crude products were purified through silica gel column chromatography using $n$-hexane:EtOAc (9:1) as eluent.

2-allyl-6-methoxy-4-[(2S,3S)-7-methoxy-3-methyl-5-[(E)-prop-1-enyl]-2,3-dihydrobenzofuran-2-yl]phenol (1d): $320 \mathrm{mg}$ of compound $\mathbf{1 c}$ yielded $53 \%$ of $\mathbf{1 d}$ as white amorphous solid. ${ }^{1} \mathrm{H}$ NMR $\left(\mathrm{CDCl}_{3}\right) \delta 6.90(\mathrm{~d}, J=1.6 \mathrm{~Hz}$, H-6), $6.84(\mathrm{~d}, J=1.6 \mathrm{~Hz}, \mathrm{H}-2), 6.83\left(\mathrm{dd}, J=1.7 \mathrm{~Hz}, \mathrm{H}-2^{\prime}\right), 6.81\left(\mathrm{~d}, J=1.7 \mathrm{~Hz}, \mathrm{H}-6^{\prime}\right), 6.40$ (dd, $J=15.7$ and $1.3 \mathrm{~Hz}$, H-7'), 6.36 (dd, $J=15.7$ and $1.4 \mathrm{~Hz}, \mathrm{H}-\gamma), 6.13-6.09$ (m, H- 3 ), 6.08-5.98 (m, H-8'), 5.73 (s, OH), 5.12 (br s, H-7), $3.87\left(\mathrm{~s}, \mathrm{OCH}_{3}\right), 3.83\left(\mathrm{~s}, \mathrm{OCH}_{3}\right), 3.54-3.34(\mathrm{~m}, \mathrm{H}-8), 3.45(\mathrm{dd}, J=6.4$ and $1.1 \mathrm{~Hz}, \mathrm{H}-\alpha), 1.86(\mathrm{dd}, J=6.6$ and $\left.1.3 \mathrm{~Hz}, \mathrm{H}-9^{\prime}\right), 1.36$ (d, $\left.J=6.8 \mathrm{~Hz}, \mathrm{H}-9\right) .{ }^{13} \mathrm{C} \mathrm{NMR}\left(\mathrm{CDCl}_{3}\right) \delta 146.7$ (C-3), $146.6\left(\mathrm{C}-4^{\prime}\right), 144.2(\mathrm{C}-4), 143.5(\mathrm{C}-5)$, $136.5(\mathrm{C}-\gamma), 133.4\left(\mathrm{C}-3^{\prime}\right), 132.2(\mathrm{C}-1), 131.2\left(\mathrm{C}-6^{\prime}\right), 131.0\left(\mathrm{C}-7^{\prime}\right), 125.5\left(\mathrm{C}-2^{\prime}\right), 123.4\left(\mathrm{C}-8^{\prime}\right), 121.0(\mathrm{C}-6), 115.6$ $\left(\mathrm{C}-5^{\prime}\right), 113.3\left(\mathrm{C}-1^{\prime}\right), 109.3(\mathrm{C}-2), 107.0(\mathrm{C}-\beta), 94.0(\mathrm{C}-7), 56.1\left(\mathrm{OCH}_{3}\right), 55.9\left(\mathrm{OCH}_{3}\right), 45.5(\mathrm{C}-8), 33.9(\mathrm{C}-\alpha), 18.4$ $\left(\mathrm{C}-9^{\prime}\right), 17.5$ (C-9). HRESIMS $m / z 367.1907[\mathrm{M}+\mathrm{H}]^{+}$(calcd. for $\mathrm{C}_{23} \mathrm{H}_{27} \mathrm{O}_{4} 367.1909$ ).

3-allyl-4-hydroxy-5-methoxy-benzaldehyde (2d): $220 \mathrm{mg}$ of compound $2 \mathrm{c}$ yielded $49 \%$ of $2 \mathrm{~d}$ as white amorphous solid. ${ }^{1} \mathrm{H}$ NMR $\left(\mathrm{CDCl}_{3}\right) \delta 9.80$ (s, H-7), 7.31 (br s, H-6), 7.30 (br s, H-2), 6.07-5.93 (m, H- $\beta$ ). 5.14 (m, H- $\gamma$ ), $3.94\left(\mathrm{~s}, \mathrm{OCH}_{3}\right), 3.46(\mathrm{~d}, J=5.0 \mathrm{~Hz}, \mathrm{H}-\alpha) .{ }^{13} \mathrm{C} \mathrm{NMR}\left(\mathrm{CDCl}_{3}\right) \delta 197.1(\mathrm{C}-7), 151.1(\mathrm{C}-1), 148.1(\mathrm{C}-4), 147.0(\mathrm{C}-3)$,

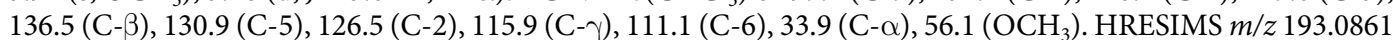
$[\mathrm{M}+\mathrm{H}]^{+}$(calcd. for $\mathrm{C}_{11} \mathrm{H}_{13} \mathrm{O}_{3}$ 193.0865).

2-allyl-4-(hydroxymethyl)-6-methoxy-phenol (3d): $220 \mathrm{mg}$ of compound 3c yielded $18 \%$ of $\mathbf{3 d}$ as white amorphous solid. ${ }^{1} \mathrm{H}$ NMR $\left(\mathrm{CDCl}_{3}\right) \delta 7.03(\mathrm{dt}, J=2.1$ and $1.0 \mathrm{~Hz}, \mathrm{H}-6), 6.76(\mathrm{~d}, J=2.1 \mathrm{~Hz}, \mathrm{H}-2), 5.86(\mathrm{tt}, J=13.4$ and $6.2 \mathrm{~Hz}, \mathrm{H}-\beta), 5.05(\mathrm{dt}, J=13.4$ and $1.0 \mathrm{~Hz}, \mathrm{H}-\gamma), 4.46(\mathrm{~s}, \mathrm{H}-7), 3.86\left(\mathrm{~s}, \mathrm{OCH}_{3}\right), 3.38(\mathrm{dt}, J=6.2$ and $1.0 \mathrm{~Hz}$, $\mathrm{H}-\alpha) .{ }^{13} \mathrm{C}$ NMR $\left(\mathrm{CDCl}_{3}\right) \delta 146.9$ (C-5), 144.6 (C-1), 136.5 (C- $\beta$ ), 132.7 (C-4), 130.1 (C-6), 124.6 (C-3), 123.3 (C-2), $113.8(\mathrm{C}-\gamma), 65.5(\mathrm{C}-7), 56.4\left(\mathrm{OCH}_{3}\right), 33.4(\mathrm{C}-\alpha)$. HRESIMS m/z $195.1023[\mathrm{M}+\mathrm{H}]^{+}\left(\right.$calcd. for $\mathrm{C}_{11} \mathrm{H}_{15} \mathrm{O}_{3}$ 195.1021).

2-allyl-6-methoxy-4-[(E)-prop-1-enyl]phenol (4d): $300 \mathrm{mg}$ of compound $\mathbf{4 c}$ yielded $43 \%$ of $\mathbf{4 d}$ as yellow liquid. ${ }^{1} \mathrm{H} \mathrm{NMR}\left(\mathrm{CDCl}_{3}\right) \delta 6.90(\mathrm{~s}, \mathrm{H}-2), 6.71(\mathrm{~s}, \mathrm{H}-6), 6.54(\mathrm{dd}, J=15.1$ and $0.8 \mathrm{~Hz}, \mathrm{H}-7), 6.24-6.21$ (m, H-8), 6.20-6.18 $(\mathrm{m}, \mathrm{H}-\beta), 5.08(\mathrm{~m}, \mathrm{H}-\gamma), 4.60(\mathrm{~d}, J=6.2 \mathrm{~Hz}, \mathrm{H}-\alpha), 3.83\left(\mathrm{~s}, \mathrm{OCH}_{3}\right), 3.36(\mathrm{~d}, J=6.2 \mathrm{~Hz}, \mathrm{H}-\alpha), 1.90(\mathrm{dd}, J=6.2$ and $0.8 \mathrm{~Hz}, \mathrm{H}-9) .{ }^{13} \mathrm{C}$ NMR $\left(\mathrm{CDCl}_{3}\right) \delta 146.9$ (C-5), 144.6 (C-4), 136.5 (C- $\beta$ ), 132.7 (C-1), 130.5 (C-7), 130.1 (C-3), $124.6(\mathrm{C}-8), 123.3\left(\mathrm{C}-2\right.$ and C-6), $113.8(\mathrm{C}-\gamma), 56.1\left(\mathrm{OCH}_{3}\right), 33.2(\mathrm{C}-\alpha), 18.9(\mathrm{C}-9)$. HRESIMS $m / z 205.1223$ $[\mathrm{M}+\mathrm{H}]^{+}$(calcd. for $\mathrm{C}_{13} \mathrm{H}_{17} \mathrm{O}_{2}$ 205.1229).

2,4-diallyl-6-methoxy-phenol (5d): $300 \mathrm{mg}$ of compound $\mathbf{5 c}$ yielded $39 \%$ of $\mathbf{5 d}$ as yellow liquid. ${ }^{1} \mathrm{H}$ NMR $\left(\mathrm{CDCl}_{3}\right) \delta 7.00$ (br s, H-6), 6.92 (br s, H-2), 6.19 (m, H- $\beta$ ), 6.18 (m, H-8), 5.18 (m, H- $\gamma$ ), 5.04 (m, H-9), 3.84 $\left(\mathrm{s}, \mathrm{OCH}_{3}\right), 3.35(\mathrm{~m}, \mathrm{H}-7) 3.30(\mathrm{~d}, J=6.1 \mathrm{~Hz}, \mathrm{H}-\alpha) .{ }^{13} \mathrm{C} \mathrm{NMR}\left(\mathrm{CDCl}_{3}\right) \delta 149.8(\mathrm{C}-5), 149.5(\mathrm{C}-4), 136.5(\mathrm{C}-8)$, 133.1 (C- $\beta$ ), 122.4 (C-6), 118.2 (C- $\gamma), 115.9$ (C-9), 114.1 (C-2), $112.3(\mathrm{C}-3), 56.1\left(\mathrm{OCH}_{3}\right), 40.0(\mathrm{C}-\alpha), 38.9(\mathrm{C}-7)$. HRESIMS $m / z 205.1225[\mathrm{M}+\mathrm{H}]^{+}$(calcd. for $\left.\mathrm{C}_{13} \mathrm{H}_{17} \mathrm{O}_{2} 205.1229\right)$.

Synthesis of compound 1 e. To $20 \mathrm{~mL}$ of a solution of $\mathbf{1 d}(0.5 \mathrm{mmol}, 180 \mathrm{mg})$ in EtOH: $\mathrm{H}_{2} \mathrm{O}(1: 10)$, three mmol of $\mathrm{I}_{2}$ were added and the mixture was stirred for $24 \mathrm{~h}$ at $25^{\circ} \mathrm{C}$. Afterwards, $15 \mathrm{~mL}$ of $\mathrm{CH}_{2} \mathrm{Cl}_{2}$ were added and treated with $\mathrm{Na}_{2} \mathrm{~S}_{2} \mathrm{O}_{3} 20 \%$ solution. The organic layer was separated, dried over anhydrous $\mathrm{Na}_{2} \mathrm{SO}_{4}$ and evaporated under reduced pressure. The crude product was then adsorbed on basic alumina (Brockmann I) and submitted to heating at $150{ }^{\circ} \mathrm{C}$ for $30 \mathrm{~min}$. After extraction with $\mathrm{CH}_{2} \mathrm{Cl}_{2}$ and evaporation of the solvent under reduced pressure, the crude product was purified on a silica gel column using $n$-hexane: $\mathrm{CH}_{2} \mathrm{Cl}_{2}(1: 1)$ as eluent to give $7 \%$ yield of $1 \mathbf{e}$ as a white amorphous solid.

7-methoxy-5-[(2S,3S)-7-methoxy-3-methyl-5-[(E)-prop-1-enyl]-2,3-dihydrobenzofuran-2-yl]2-methyl-benzofuran (1e). ${ }^{1} \mathrm{H} \mathrm{NMR}\left(\mathrm{CDCl}_{3}\right) \delta 7.21$ (br s, $\left.\mathrm{H}-2^{\prime}\right), 7.19$ (br s, $\left.\mathrm{H}-6^{\prime}\right), 7.05$ (br s, H-2 and $\mathrm{H}-\alpha$ ), 6.83 (s, H-6), 6.49-6.44 (m, H-7'), 6.25-6.20 (m, H-9'), 6.06-6.03 (m, H-8'), $5.11(\mathrm{~d}, J=9.4 \mathrm{~Hz}, \mathrm{H}-7), 4.03\left(\mathrm{~s}, \mathrm{OCH}_{3}\right)$, $3.98\left(\mathrm{~s}, \mathrm{OCH}_{3}\right), 3.46(\mathrm{dq}, J=13.6$ and $6.8 \mathrm{~Hz}, \mathrm{H}-8), 2.41(\mathrm{~s}, \mathrm{H}-\gamma), 1.38(\mathrm{~d}, J=6.8 \mathrm{~Hz}, \mathrm{H}-9) .{ }^{13} \mathrm{C} \mathrm{NMR}\left(\mathrm{CDCl}_{3}\right) \delta$ $149.6\left(\mathrm{C}-5^{\prime}\right), 148.1\left(\mathrm{C}-4^{\prime}\right), 146.6\left(\mathrm{C}-6^{\prime}\right), 145.4\left(\mathrm{C}-7^{\prime}\right), 144.1(\mathrm{C}-3), 142.0$ (C- $\left.\beta\right), 133.3(\mathrm{C}-4), 133.2(\mathrm{C}-2), 133.0$ (C-6), $132.3\left(\mathrm{C}-2^{\prime}\right), 123.5\left(\mathrm{C}-8^{\prime}\right), 119.1(\mathrm{C}-1), 115.7\left(\mathrm{C}-9^{\prime}\right), 113.1\left(\mathrm{C}-3^{\prime}\right), 110.1(\mathrm{C}-\alpha), 109.9\left(\mathrm{C}-1^{\prime}\right), 109.2(\mathrm{C}-5)$, 93.6 (C-7), $55.9\left(\mathrm{OCH}_{3}\right), 45.6(\mathrm{C}-8), 17.7(\mathrm{C}-9)$, $9.6(\mathrm{C}-\gamma)$. HRESIMS $m / z 365.1750[\mathrm{M}+\mathrm{H}]^{+}$(calcd. for $\mathrm{C}_{23} \mathrm{H}_{25} \mathrm{O}_{4}$ $365.1753)$.

Log P estimation. Log P values were calculated in silico using the Marvin Sketch 17.28.0 software (Chemaxon, Inc.). The software employs a weighted method comprised by the PhysProp data mixed with the Klopman's and Viswanadhan's calculation methods. The parameters for calculation were the default definition from the software (electrolyte concentrations for $\mathrm{Na}^{+}, \mathrm{K}^{+}$and $\mathrm{Cl}^{-}=0.1 \mathrm{~mol} / \mathrm{L}$ ). The calculated values $(\mathrm{Clog} \mathrm{P})$ are presented in Table 1.

Bioassays procedures. Experimental animals. The animal breeding facility of the Adolfo Lutz Institute (São Paulo, Brazil) provided the animal models (BALB/c mice) used in this study. Male BALB/c mice received water and food ad libitum and were maintained in sterilized cages in a controlled environment. All experimental procedures were approved by the Animal Care and Use Committee from Instituto Adolfo Lutz - Secretary of Health of São Paulo State - Brazil (Project number 04/2016), in accordance with the Guide for the Care and Use of Laboratory Animals from the National Academy of Sciences. 
Trypomastigotes and mammalian cell lines maintenance. Rhesus monkey kidney cells (LLC-MK2-ATCC CCL 7) were used for the maintenance of trypomastigotes of T. cruzi (Y strain) using RPMI-1640 medium supplemented with $2 \%$ fetal bovine serum (FBS). The cells and parasites were kept at $37^{\circ} \mathrm{C}$ in a humidified atmosphere containing $5 \% \mathrm{CO}_{2}$. Peritoneal macrophages, used in the experiments of anti-amastigote assay, were obtained by washing the peritoneal cavity of BALB/c mice, with RPMI-1640 medium supplemented with $10 \% \mathrm{FBS}$ and kept at $37^{\circ} \mathrm{C}$ in a 5\% $\mathrm{CO}_{2}$ humidified incubator. Murine conjunctive cells (NCTC clone 929, ATCC) and LLC-MK2 were kept in RPMI-1640 supplemented with 10\% FBS at the same conditions described above.

Anti-trypomastigote assay. To obtain $50 \%$ inhibitory concentration $\left(\mathrm{IC}_{50}\right.$ ) values against T. cruzi, free trypomastigotes-LLC-MK2 derived, were counted in a Neubauer hemocytometer, seeded at $1 \times 10^{6}$ cells/well (96-well plates) and incubated with serial dilutions of tested compounds $(150-1.71 \mu \mathrm{M})$, during $24 \mathrm{~h}$ in RPMI1640 medium at $37^{\circ} \mathrm{C}$ in a $5 \% \mathrm{CO}_{2}$ humidified incubator. After, resazurin $(0.011 \%$ in PBS) was added to check the viability of the parasites by 24 hours at $37^{\circ} \mathrm{C}$ in a $5 \% \mathrm{CO}_{2}$ humidified incubator. Benznidazole was used as the standard drug. The optical density was determined in FilterMax F5 (Molecular Devices) at $570 \mathrm{~nm}^{38}$.

Anti-amastigote assay. To obtain $50 \%$ inhibitory concentration $\left(\mathrm{IC}_{50}\right)$ values against intracellular amastigotes, peritoneal macrophages collected from the peritoneal cavity of BALB/c mice were used. The cells were plated on a 16-well chamber slide - NUNC (Thermo Fisher Scientific) at $1 \times 10^{5}$ cells/well and incubated for $24 \mathrm{~h}$ at $37^{\circ} \mathrm{C}$ in a $5 \% \mathrm{CO}_{2}$ humidified incubator. Next, free trypomastigotes-LLC-MK2 derived, were washed in RPMI-1640 medium, counted and used to infect the macrophages previously plated (10:1, parasite: macrophage ratio). After an incubation of $2 \mathrm{~h}$ at $37^{\circ} \mathrm{C}\left(5 \% \mathrm{CO}_{2}\right.$ humidified incubator), residual free parasites were removed by washing with RPMI-1640 medium. Tested compounds were subsequently incubated with infected macrophages for $48 \mathrm{~h}$ at $37^{\circ} \mathrm{C}\left(5 \% \mathrm{CO}_{2}\right.$ humidified incubator $)$ in different nontoxic concentrations. Benznidazole was used as standard drug. At the end of the assay, slides were fixed with $\mathrm{MeOH}$ and stained with Giemsa, counted under a light microscope (EVOS M5000, Thermo, USA) and $\mathrm{IC}_{50}$ values were determined by the infection index ${ }^{39}$.

Cytotoxicity against mammalian cells. NCTC cells-clone L929 $\left(6 \times 10^{4}\right.$ cells/well $)$ were seeded and incubated with tested compounds $(200-1.56 \mu \mathrm{M})$ for $48 \mathrm{~h}$ at $37^{\circ} \mathrm{C}$ in a $5 \% \mathrm{CO}_{2}$ humidified incubator. Cytotoxic concentration $\left(\mathrm{CC}_{50}\right)$ was determined by MTT assay ${ }^{40}$. Optical density was determined in FilterMax F5 (Molecular Devices) at $570 \mathrm{~nm}$. Selectivity Index (SI) was determined using the following ratio: $\mathrm{CC}_{50}$ against $\mathrm{NCTC}$ cells/IC ${ }_{50}$ against parasites.

Statistical analysis. $\quad \mathrm{IC}_{50}$ and $\mathrm{CC}_{50}$ values were calculated using a sigmoid dose-response curves in Graph-Pad Prism 5.0 software (GraphPad Software - San Diego, CA, USA). For the mechanism of action studies one-way ANOVA (Turkey's Multiple Comparison test) was used for significance $(\mathrm{p}<0.05)$. The assays were repeated at least twice and the samples were tested in duplicate.

Assessment of the apparent permeability through PAMPA intestinal model. Intestinal permeability of tested compounds was estimated applying the PAMPA model previously developed and validated ${ }^{37}$. Briefly, stock solutions were prepared in dimethyl sulfoxide (DMSO) at the concentrations of $10 \mathrm{mM}$ and then diluted with Tris buffer to give the final concentration donor solution at $300 \mu \mathrm{M}$ and $5 \%$ DMSO. The assay procedure was initiated by filling each well of the microtiter plate (MultiScreen, catalogue no. MATRNPS50, Millipore Corporation, Bedford, MA, USA) with $300 \mu \mathrm{L}$ of each donor drug solution. Carefully, and avoiding the pipette tip contact with the filter, the hydrophobic filter $(0.45 \mu \mathrm{m})$ of each acceptor well of the 96-well microfilter plate (MultiScreen-IP, catalogue no. MAIPNTR10, Millipore Corporation, Bedford, MA, USA) was adsorbed with $6 \mu \mathrm{L}$ of the artificial lipid solution which was composed of $2 \%$ of L- $\alpha$-phosphatidylcholine from soybean dissolved, by sonication, in $n$-dodecane. Immediately after this application, $150 \mu \mathrm{L}$ of Tris buffer containing 5\% DMSO was added to the receiving well. The receiving well was mounted on the donor plate, keeping the underside of the membrane in contact with the donor solution. The assembled donor-acceptor plates were incubated under constant stirring $(3 \mathrm{~g})$ at $25^{\circ} \mathrm{C}$ for approximately $16 \mathrm{~h}$. Subsequently, the quantity of each compound presented at the receptor solution $(150 \mu \mathrm{L})$ was determined by UV/VIS spectrophotometrically. The experiments were performed in hexaplicates $(n=6)$ and the apparent permeability coefficient (Papp) calculated in centimeters per second $(\mathrm{cm} / \mathrm{s})$, together with the standard deviation (SD). Compounds with Papp equal to or higher than $1.0 \times 10^{-6} \mathrm{~cm} / \mathrm{s}$ are classified as with high intestinal absorption $(>85 \%)$ but if it is higher than $1.0 \times 10^{-5} \mathrm{~cm} / \mathrm{s}$ they also exhibit a plasma protein binding higher than $90 \%{ }^{41}$.

Assessment of the apparent permeability through PAMPA-BBB model. The methodology herein applied was similar to that described in the previous section, however with the purpose of assessing the permeability of the compounds through the blood brain barrier (BBB). Thus, stock solutions $(10 \mathrm{mM})$ of each test compound were prepared in DMSO and diluted with phosphate buffered saline (PBS) at $\mathrm{pH}$ 7.4. The final concentration of donor solutions was $300 \mu \mathrm{M}$ and DMSO of 5\%. Artificial membrane lipid solutions were prepared daily by dissolving, in $n$-dodecane, the porcine brain lipid extracted as described ${ }^{40}$ at the final concentration of $2 \%(\mathrm{~m} / \mathrm{v})$. PAMPA procedure was similar to that described in the previous section although, in PAMPA-BBB, the donor and acceptor solutions were prepared using phosphate buffer saline (PBS) at pH 7.4 and the Papp was obtained through the equation previously reported ${ }^{42}$. Accordingly, compounds with values of Papp equal to or higher than $2.0 \mathrm{~cm} / \mathrm{s}$ are classified as permeable through BBB while those with compounds with lower values of Papp are classified as compounds that do not cross BBB. 
Cell membrane permeability analysis. The action of compounds $\mathbf{1 d}, \mathbf{1 e}, \mathbf{3 d}$ and $\mathbf{4 a}$ in the cell membrane permeability were evaluated in T. cruzi trypomastigotes $\left(2 \times 10^{6} /\right.$ well $)$ seeded in 96 -well black polystyrene microplates. Parasites were washed and incubated in the dark with $1 \mu \mathrm{M}$ SYTOX Green probe (Molecular Probes) in HANKS' balanced salts solution (HBSS; Sigma-Aldrich) supplemented with $10 \mathrm{mM}$ D-Glucose (HBSS + Glu) in 96-well black polystyrene microplates ${ }^{43,44}$. Each compound was added $(\mathrm{t}=0 \mathrm{~min})$ at $\mathrm{IC}_{50}$ concentration and fluorescence levels were measured every $20 \mathrm{~min}$ for up to $120 \mathrm{~min}$. The maximum permeabilization was obtained with the addiction of $0.5 \%$ Triton X-100. Fluorescence intensities were determined using a fluorimetric microplate reader (FilterMax F5 Multi-Mode Microplate Reader-Molecular Devices) with excitation and emission wavelengths of 485 and $520 \mathrm{~nm}$, respectively. The following internal controls were used in the evaluation: i) the background fluorescence of the compound at the respective wavelengths, ii) the possible interference of DMSO.

Analysis of reactive oxygen species (ROS). Trypomastigotes $\left(2 \times 10^{6}\right.$ parasites/well) were seeded in 96 -well black polystyrene microplates and treated with compounds $\mathbf{1 d}, \mathbf{1 e}, \mathbf{3 d}$ and $\mathbf{4 a}$ (at $\mathrm{IC}_{50}$ value) for 1 and $2 \mathrm{~h}$ in $\mathrm{HBSS}+\mathrm{Glu}$ at $37^{\circ} \mathrm{C}$. After, $\mathrm{H}_{2} \mathrm{DCFDA}$ probe (Molecular Probes) was added $(5 \mu \mathrm{M})$ and incubated by $15 \mathrm{~min}^{44}$. The fluorescence intensity was measure using a fluorimetric microplate reader (FilterMax F5 Multi-Mode, Molecular Devices) with excitation and emission wavelengths of 485 and $520 \mathrm{~nm}$, respectively. Azide (10 mM) was used as positive control and untreated parasites were used as negative control.

Analysis of ATP generation. Trypomastigotes $\left(2 \times 10^{6}\right.$ parasites/well $)$ were treated with compounds 1 d, 1e, 3d and $\mathbf{4 a}$ (at $\mathrm{IC}_{50}$ value) in HBSS + Glu for 1 and $2 \mathrm{~h}$ at $37^{\circ} \mathrm{C}$. Untreated parasites and treated with the mitochondrial uncoupler CCCP (carbonyl cyanide $m$-chlorophenylhydrazone - Sigma) at $100 \mu \mathrm{M}$, were used as positive and negative controls, respectively. The trypomastigotes were lysed using $0.5 \%$ Triton X-100 and mixed with a standard reaction buffer (ATP Determination Kit, Molecular Probes) containing DTT (1 mM), luciferin $(0.5 \mathrm{mM})$ and firefly luciferase $(1.25 \mu \mathrm{g} / \mathrm{mL})$. Luminescence intensity was measured using a luminometer (FilterMax F5 Multi-Mode, Molecular Devices) and the amount of ATP was calculated from an ATP standard curve ${ }^{45}$.

Evaluation of the mitochondrial membrane potential $(\Delta \Psi m)$. The $\Delta \Psi \mathrm{m}$ were analyzed by flow cytometry (Attune NxT flow cytometer - ThermoFisher) with the probe 5,5',6,6'-tetrachloro-1,1',3,3'-tetraethylbenzimidazole carbocyanide iodide (JC-1, ThermoFisher). The ratio between red/green fluorescence intensities (BL-2/BL-1; $590 \mathrm{~nm} / 530 \mathrm{~nm})$ were calculated ${ }^{45,46}$. Trypomastigotes $\left(2 \times 10^{6} /\right.$ tube $)$ treated for $2 \mathrm{~h}$ with the selected compounds ( $\mathrm{IC}_{50}$ values) were washed in HBSS + Glu and ressuspended with JC-1 dye at a final concentration of $10 \mu \mathrm{M}$. The parasites were incubated in the dark for $10 \mathrm{~min}$ at $37^{\circ} \mathrm{C}$ and washed in HBSS + Glu to eliminate the non-internalized dye. As internal controls of the assay were used: (i) non-treated cells and (ii) trypomastigotes treated with $100 \mu \mathrm{M}$ CCCP.

Received: 13 December 2019; Accepted: 20 February 2020;

Published online: 25 March 2020

\section{References}

1. Martins-Melo, F. R., Carneiro, M., Ribeiro, A. L. P., Bezerra, J. M. T. \& Werneck, G. L. Burden of Chagas disease in Brazil, 1990-2016: findings from the global burden of disease study. International Journal of Parasitology 49, 301-310 (2016).

2. Antinori, S. et al. Chagas disease in Europe: A review for the internist in the globalized world. European Journal of Internal Medicine 43, 6-15 (2017)

3. Malik, L. H., Singh, G. D. \& Amsterdam, E. A. The epidemiology, clinical manifestations, and management of chagas heart disease. Clinical Cardiology 38, 565-569 (2015).

4. Vieira, J. L. et al. Chagas cardiomyopathy in Latin America review. Current Cardiology Reports 21, 8 (2019).

5. Echeverria, L. E. \& Morillo, C. A. American Trypanosomiasis (Chagas Disease). Infectious Disease Clinics of North America 33, 119-134 (2019).

6. Morillo, C. A. et al. BENEFIT Investigators. randomized trial of benznidazole for chronic Chagas' cardiomyopathy. New England Journal of Medicine 373, 1295-1306 (2015).

7. Pecoul, B. et al. The BENEFIT trial: where do we go from here? PLoS Neglected Tropical Diseases 25, e0004343 (2016).

8. Muñoz, C., Zulantay, I. \& Apt, W. Evaluation of nifurtimox treatment of chronic Chagas disease by means of several parasitological methods. Antimicrobial Agents \& Chemotheraphy 57, 4518-4523 (2013).

9. Katsuno, K. et al. Hit and lead criteria in drug discovery for infectious diseases of the developing world. Nature Reviews Drug Discovery 14, 751-758 (2015).

10. Shen, B. A New golden age of natural products drug discovery. Cell 163, 1297-1300 (2015).

11. Che, C.-T. \& Zhang, H. Plant natural products for human health. International Journal of Molecular Sciences 20, 830-833 (2019).

12. Schmidt, T. J. et al. The potential of secondary metabolites from plants as drugs or leads against protozoan neglected diseases - part I. Current Medicinal Chemistry 19, 2128-2175 (2012).

13. Gómez-Cansino, R. et al. Natural compounds from mexican medicinal plants as potential drug leads for anti-tuberculosis drugs. Anais da Academia Brasileira de Ciencias 89, 31-43 (2017).

14. León-Díaz, R. et al. Antitubercular activity and the subacute toxicity of (-)-licarin A in BALB/c mice: a neolignan isolated from Aristolochia taliscana. Archives of Medical Research 44, 99-104 (2013).

15. Pereira, A. C. et al. Schistosomicidal and trypanocidal structure-activity relationships for ( \pm )-licarin A and its ( -$)$ - and (+)-enantiomers. Phytochemistry 72, 1424-1430 (2011).

16. Cabral, M. M. et al. Neolignans from plants in Northeastern Brazil (Lauraceae) with activity against Trypanosoma cruzi. Experimental Parasitology 124, 319-324 (2010).

17. Meleti, V. R. et al. $( \pm)$-Licarin A and its semi-synthetic derivatives: In vitro and in silico evaluation of trypanocidal and schistosomicidal activities. Acta Tropica 202, 105248 (2019).

18. Néris, P. L. N. et al. Neolignan licarin A presents effect against Leishmania (Leishmania) major associated with immunomodulation in vitro. Experimental Parasitology 135, 307-313 (2013).

19. Barbosa-Filho, J. M., Cunha, E. V. L. \& Silva, M. S. Complete assignment of the $1 \mathrm{H}$ and 13C NMR spectra of some lignoids from Lauraceae. Magnetic Resonance in Chemistry 36, 929-935 (1998). 
20. Corrêa, M. F. et al. Factorial design study to access the "green" iodocyclization reaction of 2-allylphenols. Green Processing and Synthesis 5, 145-151 (2016).

21. Pancote, C.G., et al. Simple and efficient access to 3-ethoxycarbonylpyrroles, naphthofurans. Synthesis, 3963-3966 (2009).

22. Barreiro, E. J. Estratégia de simplificação molecular no planejamento racional de fármacos: a descoberta de novo agente cardioativo. Quimica Nova 25, 1172-1180 (2002).

23. Wang, S., Dong, G. \& Sheng, C. Structural simplification of natural products. Chemical Reviews 119, 4180-4220 (2019).

24. Gao, Y., Gesenberg, C. \& Zheng, W. Oral Formulations for Preclinical Studies, Developing Solid Oral Dosage Forms. Elsevier, 455-495 (2017).

25. Hughes, J. D. et al. Physiochemical drug properties associated with in vivo toxicological outcomes. Bioorganic and Medicinal Chemistry Letters 18, 4872-4875 (2008).

26. Sanchez-Moreno, M., Fernandez-Becerra, M., Castilla-Calvente, J. J. \& Osuna, A. Metabolic studies by 1H NMR of different forms of Trypanosoma cruzi as obtained by in vitro culture. FEMS Microbiology Letters 133, 119-125 (1995).

27. Cazzulo, J. J. Energy Metabolism in Trypanosoma cruzi, in: J.L., Avila, J.R., Harris (Eds.), Intracelular Parasites, 235-257 (1992).

28. Arauzo, S. \& Cazzulo, J. J. The NADP-linked aldehyde reductase from Trypanosoma cruzi subcellular localization and some properties. FEMS Microbiology Letters 58, 283-286 (1989).

29. Berná, L. et al. Transcriptomic analysis reveals metabolic switches and surface remodeling as key processes for stage transition in Trypanosoma cruzi. Peer J. 5, e3017 (2017).

30. Oliveira, E. A. et al. Antitrypanosomal activity of acetogenins isolated from the seeds of Porcelia macrocarpa is associated with alterations in both plasma membrane electric potential and mitochondrial membrane potential. Journal of Natural Products 82, $1177-1182(2019)$.

31. Pal, C. \& Bandyopadhyay, U. Redox-active antiparasitic drugs. Antioxidant Redox Signal 4, 555-582 (2012).

32. Zorova, L. D. et al. Mitochondrial membrane potential. Analytical Biochemistry 552, 50-59 (2018).

33. Tomás, A. M. \& Castro, H. Redox metabolism in mitochondria of trypanosomatids. Antioxidant \& Redox Signaling 19, 696-707 (2013).

34. Figueira, T. R. et al. Mitochondria as a source of reactive oxygen and nitrogen species: from molecular mechanisms to human health. Antioxidant \& Redox Signaling 18, 2029-2074 (2013).

35. Lipinski, C. A., Lombardo, F., Dominy, B. W. \& Feeney, P. J. Experimental and computational approaches to estimate solubility and permeability in drug discovery and development settings. Advanced Drug Delivery Reviews 46, 3-26 (2001).

36. Congreve, M., Carr, R., Murray, C. \& Jhoti, H. A 'Rule of Three' for fragment-based lead discovery? Drug Discovery Today 8, 876-877 (2003).

37. Fortuna, A., Alves, G., Soares-da-Silva, P. \& Falcão, A. Optimization of a parallel artificial membrane permeability assay for the fast and simultaneous prediction of human intestinal absorption and plasma protein binding of drug candidates: application to dibenz[b,f] azepine-5-carboxamide derivatives. Journal of Pharmaceutical Sciences 101, 530-540 (2012).

38. Mikus, J. \& Steverding, D. A simple colorimetric method to screen drug cytotoxicity against Leishmania using the dye Alamar blue. Parasitology International 48, 265-269 (2000).

39. Reimão, J. Q., Colombo, F. A., Pereira-Chioccola, V. L. \& Tempone, A. G. In vitro and experimental therapeutic studies of the calcium channel blocker bepridil: detection of viable Leishmania (L.) chagasi by real-time PCR. Experimental Parasitology 128, $111-5(2011)$.

40. Tada, H., Shiho, O., Kuroshima, K., Koyama, M. \& Tsukamoto, K. An improved colorimetric assay for interleukin 2. Journal of Immunology Methods 93, 157-165 (1986).

41. Avdeef, A. \& Tsinman, O. PAMPA - a drug absorption in vitro model 13. Chemical selectivity due to membrane hydrogen bonding: In combo comparisons of HDM-, DOPC-, and DSPAMPA models. European Journal of Pharmaceutical Sciences 28, 43-50 (2006).

42. Bicker, J., Alves, G., Fortuna, A., Soares-da-Silva, P. \& Falcão, A. A new PAMPA model using an in-house brain lipid extract for screening the blood-brain barrier permeability of drug candidates. International Journal of Pharmacology 501, 102-111 (2016).

43. Mangoni, M. L. et al. Temporins, small antimicrobial peptides with leishmanicidal activity. Journal of Biological Chemistry 280, 984-990 (2005).

44. Mesquita, J. T., Costa-Silva, T. A., Borborema, S. E. \& Tempone, A. G. Activity of imidazole compounds on Leishmania (L.) infantum chagasi: reactive oxygen species induced by econazole. Molecular and Cellular Biochemistry 389, 293-300 (2014).

45. Amaral, M. et al. A semi-synthetic neolignan derivative from dihydrodieugenol B selectively affects the bioenergetic system of Leishmania infantum and inhibits cell division. Scientific Reports 9, 6114 (2019).

46. Keil, V. C., Funke, F., Zeug, A., Schild, D. \& Müller, M. Ratiometric high-resolution imaging of JC-1 fluorescence reveals the subcellular heterogeneity of astrocytic mitochondria. Pflügers Archiv: European Journal of Physiology 462, 693-708 (2011).

\section{Acknowledgements}

The authors thanks to São Paulo Research Foundation - FAPESP (grants 2018/07885-1, 2018/10279-6, 2016/20633-6, and 2016/25028-3), CAPES (financial code 001), and National Council for Scientific and Technological Development - CNPq (455411/2014-0), for financial support. TRM thanks PDSE grant $\mathrm{n}$. 88881.134147/2016-01. AF and ACF thank Chemaxon for licensing software for PK study. AGT, JPSF and JHGL are grateful to CNPq for the scientific award grants. This publication is part of the activities of the Research Network Natural Products against Neglected Diseases (ResNetNPND): http://www.uni-muenster.de/ ResNetNPND/.

\section{Author contributions}

T.R.M., G.A.A.C., V.P., and T.A.C.S. contributed to the bioactivity tests, mechanism of action studies and manuscript preparation. A.G.T. assisted with the mechanism of action studies. T.R.M., M.T.V., and J.P.S.F. prepared the semi-synthetic compounds. G.A.A.C., V.P., F.T., and J.H.G.L. contributed to the isolation and identification of the licarin A. T.R.M., A.F., and A.C.F. conducted the in silico analysis. J.H.G.L., A.G.T. and J.P.S.F. proposed the idea and prepared the manuscript. All authors read, revised and approved the manuscript.

\section{Competing interests}

The authors declare no competing interests.

\section{Additional information}

Supplementary information is available for this paper at https://doi.org/10.1038/s41598-020-62352-w.

Correspondence and requests for materials should be addressed to J.P.S.F. or J.H.G.L.

Reprints and permissions information is available at www.nature.com/reprints. 
Publisher's note Springer Nature remains neutral with regard to jurisdictional claims in published maps and institutional affiliations.

(c) (i) Open Access This article is licensed under a Creative Commons Attribution 4.0 International License, which permits use, sharing, adaptation, distribution and reproduction in any medium or format, as long as you give appropriate credit to the original author(s) and the source, provide a link to the Creative Commons license, and indicate if changes were made. The images or other third party material in this article are included in the article's Creative Commons license, unless indicated otherwise in a credit line to the material. If material is not included in the article's Creative Commons license and your intended use is not permitted by statutory regulation or exceeds the permitted use, you will need to obtain permission directly from the copyright holder. To view a copy of this license, visit http://creativecommons.org/licenses/by/4.0/.

(c) The Author(s) 2020 